\title{
The Compounds Responsible for the Sensory Profile in Monovarietal Virgin Olive Oils
}

\author{
Cristina Campestre ${ }^{1, *}$ (D), Guido Angelini ${ }^{1}$ (D) Carla Gasbarri $^{1}{ }^{(1)}$ and Franca Angerosa ${ }^{2}$ \\ 1 Department of Pharmacy, University “G. d'Annunzio" of Chieti-Pescara, via dei Vestini, 66100 Chieti, Italy; \\ guido.angelini@unich.it (G.A.); carla.gasbarri@unich.it (C.G.) \\ 2 Council for Agricultural Research and Economics (CREA), CREA-OLI Olive Growing and Oil Industry \\ Research Centre, Viale Petruzzi 75, Città Sant'Angelo (PE) 65013, Italy; franca.angerosa@virgilio.it \\ * Correspondence: cristina.campestre@unich.it; Tel.: +39-0871-355-4584
}

Received: 9 October 2017; Accepted: 25 October 2017; Published: 27 October 2017

\begin{abstract}
Monovarietal virgin olive oils (VOOs) are very effective to study relationships among sensory attributes, the compounds responsible for flavour, and factors affecting them. The stimulation of the human sensory receptors by volatile and non-volatile compounds present in monovarietal virgin olive oils gives rise to the sensory attributes that describe their peculiar delicate and fragrant flavours. The formation of these compounds is briefly illustrated and the influence of the agronomic and technological factors that affect their concentrations in the oil is examined. The relationships between compounds responsible for the olive oil flavour and sensory attributes are discussed. Several approaches for the varietal differentiation of monovarietal virgin olive oils are also overviewed.
\end{abstract}

Keywords: virgin olive oil; volatiles; phenolic compounds; sensory characteristics; cultivar; agronomic and technological factors

\section{Introduction}

Virgin olive oils (VOOs) are unique among other vegetable oils. They are only mechanically extracted and can be consumed without any further refining process, thus preserving natural compounds, very important for their nutritional value, which give rise to their unique aroma and taste $[1,2]$. The fragrant and delicate flavour of VOOs is usually described by perceptions ascribable to fruity, the sensation reminiscent of the healthy olive fruit harvested at the optimum time of its ripeness, and by perceptions reminiscent of just cut grass, leaf, floral notes, green fruits (e.g., apple, banana, almond) or vegetables (e.g., tomato, artichoke), accompanied by more or less intense bitterness and pungency notes [3].

VOOs are rich in phenolic compounds that possess beneficial biological activities [4-17]. A significant effect in the prevention of several important diseases, all related to high concentrations of free radicals, is attributed to phenolic compounds, because of their antioxidant activity [4]. The protective activity against atherosclerosis and cardiovascular diseases $[5,6,8,16,17]$, against several kinds of cancer $[7,16]$ and against cognitive deficits and neuropathology is attributable to the free radical scavenging activity [9]. Phenolic compounds also contribute to the formation of oil flavour, as they are responsible for gustative and trigeminal sensory notes. Bitterness and pungency, characteristic attributes of fresh high quality oils, show the highest intensities, according to cultivar, when oils are obtained from not completely ripe fruits, and are also related to phenolic compounds.

Among the sensations experienced by assessors during virgin olive oil tasting, only bitterness, pungency and astringency are related to the stimulation of the gustative and trigeminal receptors from non-volatile compounds; the remaining manifold sensations are elicited by the stimulation of olfactory receptors by volatile compounds. This fraction, responsible for the unique aroma of VOOs, 
plays a very important role in human nutrition, stimulating the appetite and the gratifying effect, thus affecting the food acceptability and directing consumer preference [18,19].

\section{Compounds Responsible for the Monovarietal VOOs Flavour}

\subsection{Phenolic Compounds}

The interest in olive phenolic compounds has greatly increased recently, because of their antioxidant abilities $[4,5,14,20,21]$, associated with both their nutraceutical properties [10-13,17,22-25], the high stability they confer to the resulting olive oil during storage [4,26-31], and their sensory impact [32,33].

Phenolic compounds in VOOs are responsible for the positive sensory attributes of bitterness and pungency $[3,32,34]$. The intensity of these attributes, and therefore the pleasantness of a VOO, depends on the concentration of phenolic compounds [34-37]. However, when the amount of phenols in VOOs is very high, the intensities of bitterness and/or pungency are very strong and many people with a special sensitivity to these attributes can reject this kind of oils, preferring oils characterized by pleasant green aroma and light-medium strength of bitter and pungent notes [18,19,38-40].

The phenolic fraction of VOOs is formed only in a little part by simple phenols, mainly hydroxytyrosol (3,4-dihydroxyphenylethanol: 3,4-DPHEA) and tyrosol ( $p$-hydroxyphenylethanol: $p$-HPEA), but also caffeic acid and some hydroxybenzoic and hydroxycinnamic acid derivatives. Most of the phenolics in VOOs is represented by aglycons of secoiridoid glucosides [41-44], namely oleuropein and ligstroside, naturally occurring in the fruit and exclusively present in plants belonging to the Oleaceae family. While only trace levels of oleuropein have been detected in VOOs [45], the secoiridoid aglycons, produced during the oil extraction process as the result of the $\beta$-glucosidase activity, are partly dissolved into the oil. The most abundant are 3,4-DHPEA-EDA and $p$-HPEA-EDA, the dialdehydic forms of elenolic acid (EDA) linked to 3,4-DHPEA and $p$-HPEA respectively, and an isomer of the oleuropein aglycon (3,4-DHPEA-EA) [12,13]. An additional class of phenolics, namely the lignans, isolated and characterized in VOOs [46,47] is represented by 1-acetoxypinoresinol and pinoresinol.

Numerous studies have been carried out to clarify the relationship between taste attributes in VOOs and their phenolic compound contents: bitterness intensity was initially related to the presence of oleuropein derivatives [48-50], but other researchers, on the basis of sensory evaluations and amount of some phenolic compounds, have attributed the bitter sensory note to both oleuropein and ligstroside aglycons [33,51], or only to ligstroside derivatives such as $p$-HPEA-EDA [52].

In 2003 Andrewes and co-workers [32] separated the single phenolic compounds and evaluated their sensory characteristics. On the basis of the estimated taste threshold reported by the same authors, the main contribution to pungent attribute is given by the fraction containing p-HPEA-EDA, namely the deacetoxyligstroside aglycon, which elicited a strong burning pungent sensation at the back of the throat. In contrast, the fraction containing 3,4-DHPEA-EDA, at an equivalent concentration, produced only a slight burning/numbing sensation, which was perceived more on the tongue. No other phenolic fractions produced the intense burning sensation. Astringent attribute was mainly related to 3,4-DHPEA-EA, even if also other fractions contributed to elicit this sensation. Beauchamp et al. [53] isolated $p$-HPEA-EDA from different virgin olive oils, and measured the pungent intensity, confirming this compound as the principal responsible for throat irritation. Secoiridoid derivatives of oleuropein and demethyloleuropein such as 3,4-DHPEA-EDA and 3,4-DHPEA-EA have been found to be the main contributors of VOO bitterness [54]; simple phenols, lignans and flavones could not elicit any bitter sensation.

\subsection{Volatile Compounds}

A great number of volatile compounds belonging to several chemical classes, especially carbonyl compounds, alcohols, esters and hydrocarbons, have been found in the volatile fraction of VOOs $[55,56]$. 
Lists of the different compounds, identified and assigned by GC-MS technique, were previously reported in the literature $[57,58]$. The C6 and C5 compounds, especially C6 linear unsaturated and saturated aldehydes, represent the most abundant fraction of volatile compounds of high quality VOOs [59-61]. Other compounds belong to hydrocarbons, acids, ethers, oxygenate terpenes, furan and thiophene derivatives. Some of the volatiles occurring in VOOs of different quality arise from the activities of certain microorganisms and/or moulds [62-66]. Pseudomonas and Clostridium genera produce five carbon branched alcohols determining the appearance of fusty defect [62]. Yeasts and/or Acetobacter accumulate ethanol, ethyl acetate and acetic acid, as result of their activities: quite large amounts of these compounds are responsible for the winey/vinegary defect [65]; butyrates and 2-ethyl butyrates, related to muddy sediment off-flavour, are formed by butyric fermentation of micro-organisms belonging to the Clostridium genus [57]. Numerous Aspergillus and Penicillium genera are involved in the production of C8 primary and secondary alcohols and C8 ketones, responsible for musty defect [63]. Furthermore, the accumulation of products arising from the hydroperoxides fragmentation in oils that have suffered an oxidizing process is responsible for rancid sensory defect [61].

Several pathways contribute to the production of volatile compounds of VOOs and the different sensory nuances that can be appreciated depend on the relative importance of each pathway (Figure 1).

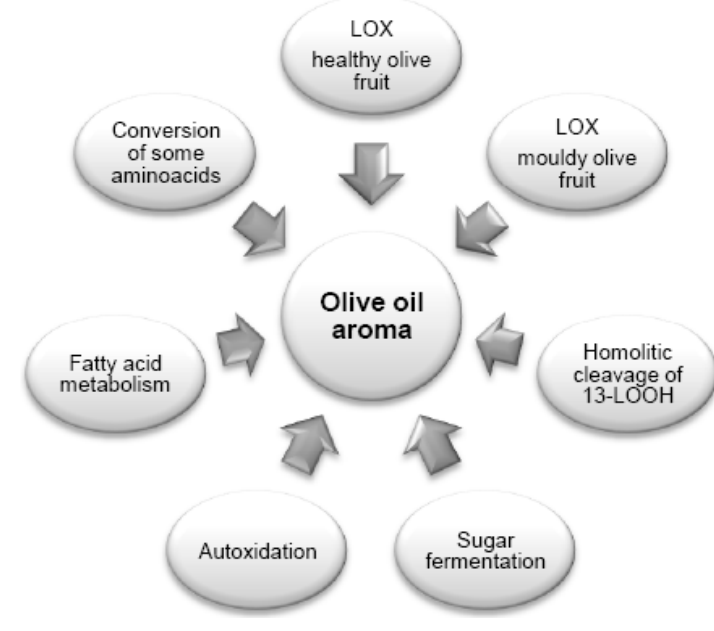

Figure 1. The main pathways involved in the formation of volatile compounds in VOOs.

The level and the activity of the different enzymes that are involved in the pathways affect the qualitative and quantitative composition of the volatile fraction; their content is regulated by genetic factors, whereas their activity is modulated by agronomic and technological variables [55,57,67]. Newly formed compounds, deriving from phenomena of degradation, fermentation and autoxidation, are added to compounds coming from the pathways typical of fruits. Some of them are active in olive fruit, other ones during oil extraction.

In high quality VOOs, the contribution of pathways involving activities of microorganisms or autoxidation process is practically negligible, and therefore only the lipoxygenase (LOX), the homolytic cleavage of hydroperoxides (13-LOOH) pathways and the conversion of leucine, valine and isoleucine are really active [57,68]; among them, because of the considerable amounts of corresponding metabolites, the major activity is displayed by LOX pathway.

Most of volatiles are rapidly formed during the olive crushing, owing to the disruption of olive cells [69]. Their production also continues during the malaxation step of olive processing.

Volatiles are biosynthesized in plants as a response to cell disruption from C18 unsaturated fatty acids containing a cis,cis-1,4-pentadiene structure, namely linolenic (LnA) and linoleic (LA) acids, by a LOX oxidation [59-61]. The pathway starts from the oxidation of linolenic (LnA) and linoleic (LA) 
acids mediated by LOXs, and a number of other enzymatic activities lead to the accumulation of C6 volatile compounds (Figure 2).

In addition C10 hydrocarbons (also known as pentene dimers) and C5 alcohols, namely 2-penten-1-ol and 1-penten-3-ol, would be produced from the LnA hydroperoxide through an additional pathway, partly enzymatic, that involves an alkoxyl radical; the subsequent oxidation of C5 alcohols could lead to C5 carbonyl compounds [70].

The LOX pathway involves, in addition to the activity of LOX [71], in sequence those of hydroperoxide lyases (HPL) [72], alcohol dehydrogenases (ADH) [73], and alcohol acetyl transferases (AAT) [74], whose levels are genetically determined, so that, according to their individual content and activity, there is a different accumulation of $\mathrm{C} 6$ and $\mathrm{C} 5$ compounds, accounting for the various sensory profiles of VOOs.

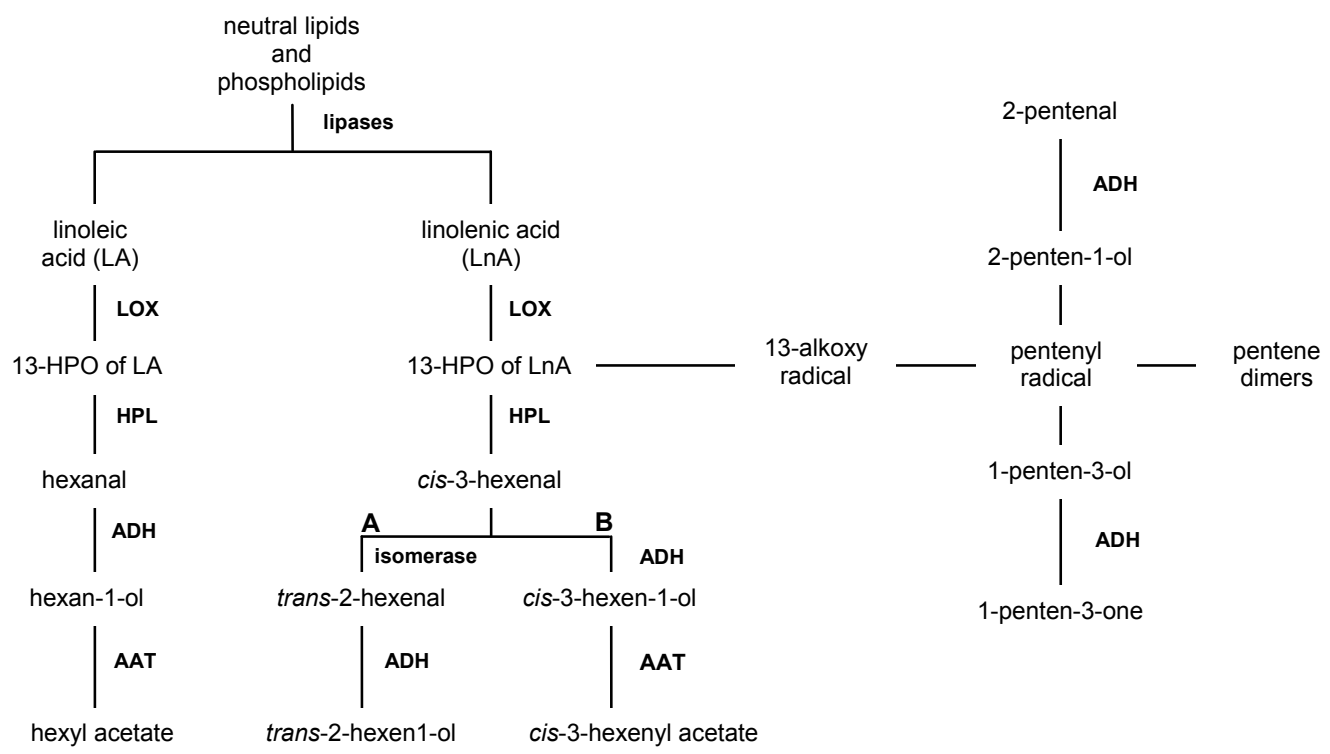

Figure 2. LOX pathway of volatile compounds in VOOs.

It is very difficult to relate each volatile to sensory perceptions. HRGC-sniffing techniques were applied by several researchers to investigate about the odour quality of compounds present in the oil aroma [58,75]. Odour qualities of volatile compounds found by different authors and corresponding references were reported in a paper [55]. Odour intensity seems to be more linked to a series of chemical factors (e.g., size, volatility, type and position of functional groups) than to concentration [75-77]. Differences in individual sensitivity of human subjects affect the evaluation of the odour intensity [78], so that the contribution of each volatiles to the oil aroma is better evaluated by the odour activity value $(\mathrm{OAV})$, that is the ratio between the concentration and the corresponding odour threshold $[79,80]$. According to Guth and Grosh $[79,80]$ the most important contributors in VOOs high quality are cis-3-hexenal, hexanal and cis-3-hexen-1-ol, because of their low odour threshold.

However the aroma of VOOs is the result of complex interactions occurring between volatiles and receptors responsible for taste, smell, sight and trigeminal and tactile perceptions [35,76,81,82]. Thus positive and negative synergisms can occur and new kinds of perceptions could be produced by the interaction between taste and odour [82]. In spite of these interactions, in literature sensory perceptions are related to the concentrations of volatile compounds. Principal component analysis (PCA) and partial least square regression (PLS) analysis were used to relate sensory and instrumental data by Servili and co-workers [83]. PLS regression gave good predictions from headspace data of some of the descriptors used in quantitative descriptive analysis. Inter-intra dissimilarities from data sets of sensory attributes and volatile components were studied by means of multidimensional scaling (MDS) [84]: volatiles completely explain the sensory perceptions, as described by different panels and 
categorized by them into aroma, odor, taste, after-taste, mouthfeel and after-mouthfeel. The plot of the first two dimensions of MDS of datasets of volatiles and sensory notes evidenced the presence of seven basic sectors (green, fruity, sweet, ripe, over-ripe, undesirable, and pungent) and volatiles responsible for them. These results were in agreement with conclusions achieved by using a sensory wheel $[38,85,86]$, a robust statistical procedure that allowed clustering into the same seven sectors sensory attributes with the same semantic description, obtained from a panel of six different countries. The position of descriptors on the sensory wheel was found consistent with the sensation elicited by the pure compound tested by HRGC sniffing methodology. The relation between sensory and instrumental data was determined by projecting volatiles onto the sensory wheel. Volatiles took up the appropriate place within the sector that corresponded to their perceptions detected by sniffing method: all cis-3 compounds from LOX pathway belonged to the green sector, hexanal was placed in the sweet one and some compounds such as trans-2-hexen-1-ol and hexan-1-ol in the undesirable sector.

Angerosa et al. [35] applied a Linear Regression Analysis (LRA) to sensory attributes perceived by panel tasters and to C5 and C6 compounds from LOX pathways and phenolic compounds. Results evidenced that hexanal plays an essential role in the formation of the majority of green attributes: this compound showed a positive correlation with sweet sensory note, and a negative one with grass and leaf sensations. trans-2-Hexenal contributed to grass perception, and 1-penten-3-one together with phenolic compounds to leaf attribute. 1-Penten-3-one and cis-3-hexen-1-ol seemed to have a synergic effect on the elicitation of bitter and pungent characters, positively correlated with phenolic compounds and negatively with hexanal. Phenolic compounds contributed to the characterization of walnut husk, whereas C5 compounds, especially 1-penten-3-one, strongly affected most attributes (Table 1).

Table 1. Green attributes correlated to volatiles from LOX pathways and to the total amount of phenolic compounds. (Source: Authors; unpublished results).

\begin{tabular}{|c|c|c|c|}
\hline Sensory Notes & $\mathbf{R}^{2}$ & Volatile Compounds Positively Related & Volatile Compounds Negatively Related \\
\hline Bitter & 0.80 & 1-penten-3-one, polyphenols & hexanal, cis-3-hexen-1-ol \\
\hline Pungent & 0.80 & 1-penten-3-one, polyphenols & hexanal, trans-2-hexenal \\
\hline Sweet & 0.72 & hexanal & trans-2-hexenal, trans-2-pentenal \\
\hline Fruity & 0.66 & cis-2-penten-1-ol & $\begin{array}{l}\text { trans-2-hexen-1-ol, trans-2-pentenal, } \\
\text { 1-penten-3-one }\end{array}$ \\
\hline Leaf & 0.65 & 1-penten-3-one, polyphenols & hexanal \\
\hline Freshly cut grass & 0.57 & trans-2-hexenal & hexanal \\
\hline Almond & 0.62 & cis-2-penten-1-ol & $\begin{array}{l}\text { trans-2-hexenal, 1-penten-3-ol, } \\
\text { cis-3-hexen-1-ol, polyphenols }\end{array}$ \\
\hline Banana & 0.60 & hexanal, cis-3-hexenyl acetate & $\begin{array}{l}\text { trans-2-pentenal, trans -2-hexenal, } \\
\text { cis-2-penten-1-ol }\end{array}$ \\
\hline Walnut husk & 0.57 & $\begin{array}{l}\text { cis-3-hexenyl acetate, } \text { trans-2-pentenal, } \\
\text { polyphenols }\end{array}$ & hexan-1-ol, cis-3-hexen-1-ol \\
\hline Wild flowers & 0.56 & trans-2-hexen-1-ol & hexyl acetate, hexanal \\
\hline Tomato & 0.51 & hexan-1-ol, 1-penten-3-one & trans-2-hexen-1-ol, hexanal, 1-penten-3-ol \\
\hline
\end{tabular}

\section{Factors Affecting Compounds Responsible for Flavour of Monovarietal VOOs}

While enzyme levels are genetic characteristics and therefore typical of the cultivar, their activity is affected by several but not less important factors, related to ripeness and growing area of fruits, time and conditions of their storage, technological aspects of oil extraction. Therefore these parameters quantitatively modify the composition of flavour compounds. Monovarietal oils are very useful for studying the influence of factors such as agronomic or technological ones on the sensory notes and on compounds responsible for their flavour. 


\subsection{Agronomic Factors}

\subsubsection{Cultivar}

Cultivar plays an essential role, as the amount of the enzymes involved in the pathways of volatile and phenolic compounds is genetically determined. The phenolic composition of olive fruit is tightly connected to genotype [87-90].

Oleuropein and demethyloleuropein are the predominant secoiridoids of olive fruit, which also contains verbascoside. The phenolic composition of olive fruits from different cultivars is also reflected on that of corresponding oils. While the phenolic profile is almost the same, the absolute concentration of each secoiridoid derivative is cultivar dependent [12]. The concentration of the lignans 1-acetoxypinoresinol and 1-pinoresinol in VOOs is strongly related to the botanical origin, and could be used as varietal index [12].

The influence of the cultivar on the volatile fraction can be evidenced by the different concentrations of these compounds if changes of the activity of enzymes involved in the LOX pathway are removed. Table 2 reports the concentrations of C6 and C 5 compounds in oils, obtained in the same operative conditions of the extraction process, from fruits of different cultivars grown in the same botanical garden and harvested at the same ripening stage.

Table 2. Levels ( $\mathrm{mg} / \mathrm{kg}$ ) of C6 and C5 volatile compounds in some extra virgin monovarietal olive oils. Results are expressed as mean of three samples of each monovarietal olive oil. $\mathrm{A}=$ all $\mathrm{C} 6$ compounds from LA; B = all C6 compounds from LnA; C = all C5 compounds. (Source: Authors; unpublished results).

\begin{tabular}{cccccccc}
\hline Compound & Dritta & Frantoio & Bosana & Moraiolo & Canino & Coratina & Koroneiki \\
\hline Hexanal & 0.7 & 2.7 & 1.2 & 0.1 & 0.5 & 0.5 & 0.8 \\
Hexan-1-ol & 0.7 & 0.3 & 0.6 & 0.2 & 0.2 & 0.1 & 0.2 \\
Hexyl acetate & 0.2 & 0.4 & 0.6 & 0.1 & traces & 0.0 & 0.2 \\
trans-Hexenal & 11.4 & 38.9 & 12.1 & 1.8 & 30.3 & 23.8 & 3.3 \\
trans-2-Hexen-1-ol & 1.5 & 0.6 & 1.5 & 0.2 & 0.9 & 0.6 & 0.1 \\
cis-3-Hexen-1-ol & 0.2 & 0.4 & 0.3 & 1.7 & 0.7 & 0.3 & 0.9 \\
cis-3-Hexenyl acetate & 0.6 & 1.3 & 1.1 & 0.4 & 0.1 & 0.1 & 2.0 \\
2-Pentenal & 0.1 & 0.2 & 0.2 & 0.1 & 0.3 & 0.3 & 0.2 \\
1-Penten-3-ol & 0.1 & 0.4 & 0.2 & 0.2 & 0.2 & 0.4 & 0.4 \\
1-Penten-3-one & 0.2 & 0.7 & 0.2 & 0.2 & 0.2 & 0.9 & 0.8 \\
cis-2-Penten-1-ol & traces & 0.6 & 0.5 & 0.2 & 0.3 & 0.4 & 0.3 \\
Pentene dimers & 0.5 & 0.7 & 0.6 & 0.5 & 1.1 & 0.6 & 2.3 \\
Total aldehydes & 12.2 & 42.0 & 13.5 & 2.0 & 31.1 & 24.6 & 4.3 \\
Total alcohols & 2.5 & 2.3 & 3.1 & 2.5 & 2.3 & 1.8 & 1.9 \\
Total esters & 0.8 & 1.7 & 1.7 & 0.5 & 0.1 & 0.1 & 2.2 \\
B/A & 8.6 & 12.1 & 6.3 & 10.3 & 45.7 & 41.3 & 5.3 \\
B/C & 15.2 & 17.2 & 8.8 & 3.4 & 15.2 & 9.5 & 1.6 \\
Total C6 and C5 & 16.2 & 47.2 & 19.1 & 5.7 & 34.8 & 28.0 & 11.5 \\
compounds & & & & & & &
\end{tabular}

The different genetic stores give rise to a different total amount of compounds from LOX pathways. trans-2-Hexenal is the most abundant compound in all the seven cultivars, but its concentration is quite different: Frantoio and Canino show the higher values, while Koroneiki and Moraiolo the lower ones. Similar contents are observed for Dritta and Bosana. These results agree with the findings of Aparicio and Luna [91], who suggested that monovarietal VOOs could be distinguished by trans-2-hexenal content. Coratina and Canino have a negligible concentration in esters, which, on the contrary, characterizes Frantoio, Bosana and especially Koroneiki. Also the ratio between total amounts of C6 compounds from LnA and LA respectively and the one between total amounts of C6 compounds from LnA and total amount of $\mathrm{C} 5$ compounds are different and evidence varietal differences. Several investigations correlated C6 and C5 compounds with green perceptions [35,61,86,92], thus the different 
concentration of $\mathrm{C} 6$ and $\mathrm{C} 5$ compounds will elicit the different nuances and intensities of green attributes. Figure 3 shows the sensory profiles of some of the oils reported in Table 2.

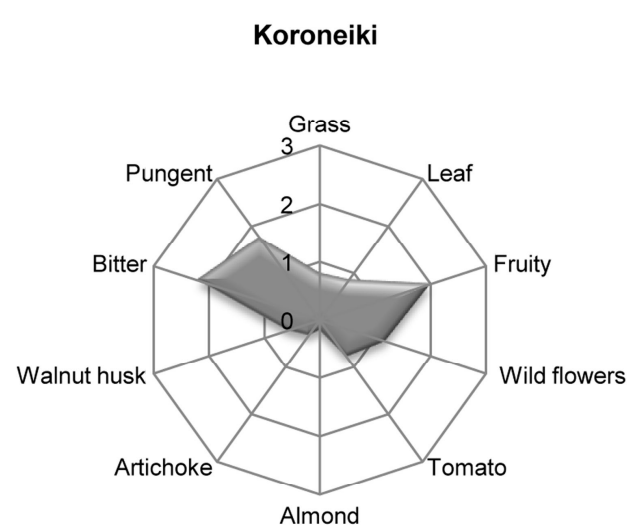

Frantoio

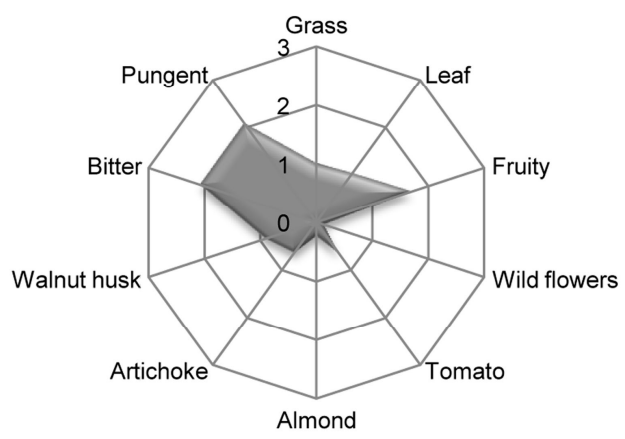

Dritta

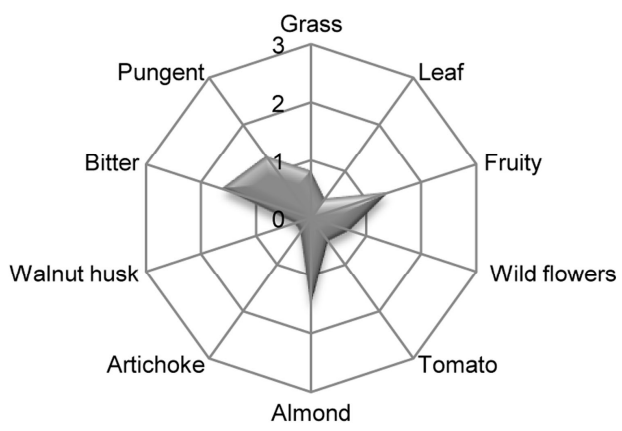

Coratina

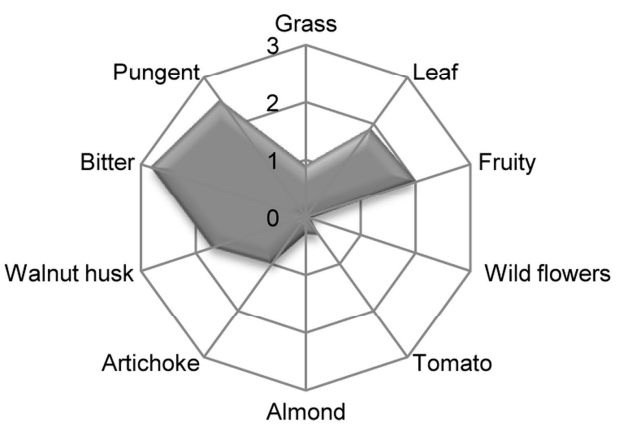

Figure 3. Sensory profiles of extra virgin monovarietal oils from Koroneiki, Dritta, Frantoio and Coratina cultivars. (Source: Authors; unpublished results).

\subsubsection{Ripening Degree}

The development and the ripening of olive fruit are a combination of biochemical and physiological events that occur under both strict genetic control and influence of several environmental conditions [93]. It is generally accepted that the content of glucosides in the fruits, and consequently that of aglycons in the oil, shows a first reduction in the green ripening phase because of an increased activity of hydrolytic enzymes; it then falls after fruits turn to purple colour [94-97].

An esterase activity has been invoked to explain the rapid decline of oleuropein in the black ripening phase [94]. Consequently to the hydrolytic activity, the amount of simple phenols increases during the ripening process $[88,95,98-101]$. The presence of high levels of phenolics enhances the nutritional and healthy properties of the resulting oils, but it is related to strong intensities of bitter and pungent, not very appreciated by habitual and potential consumers $[18,19,40]$.

The significant decrease of phenolic fraction, especially of oleuropein from spotted until black fruits, is perceived as a weakening of bitterness and pungency in VOOs $[32,54,55]$. The weakening does not only concern bitter and pungent attributes, but also the olfactory perceptions; this means that also volatile compound profile changes, according to the progress of ripeness (Figure 4). 
Spotted fruits

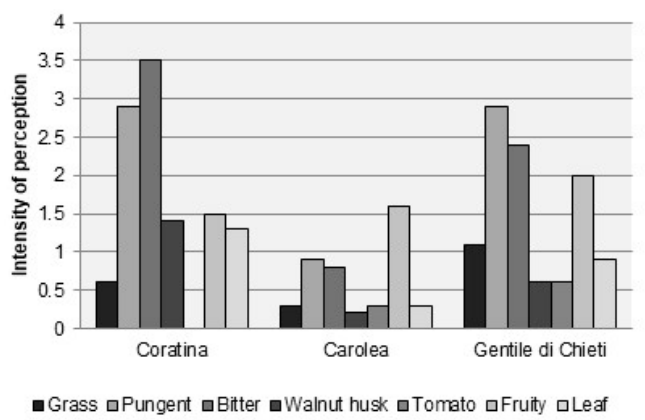

Black fruits

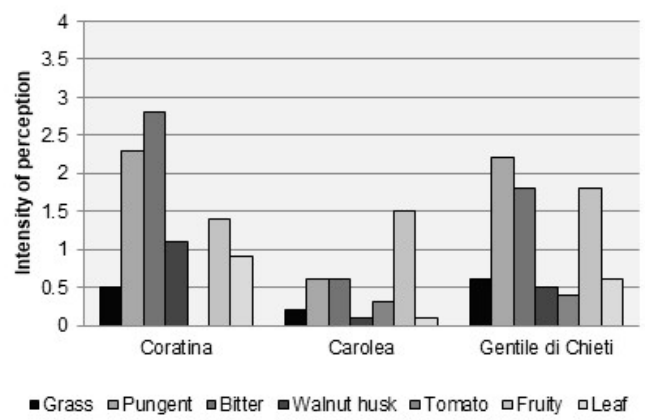

Figure 4. Sensory profiles of oils from Coratina, Carolea and Gentile di Chieti cultivars, at two different stages of ripeness. Figures were obtained on the basis of data collected by our team. Data represent the average of intensities recorded by fully trained tasters in three independent trials. The oils were presented according to an experimental design, which minimized possible biases and carry-over effects. Standard deviation ranged between $\pm 0.2-0.5$. (Source: Authors; unpublished results).

The evolution of the volatiles responsible for VOO green aroma in relation to ripening degree of fruits was studied by several researchers. Some of them [102-104], studying monovarietal oils extracted with the same plant and conditions from fruits grown in the same botanical garden, found that, during the ripening, the amount of volatiles, especially $\mathrm{C} 6$ aldehydes, increases up to a maximum concentration occurring at spotted or reddish ripening stage; beyond that point, the volatile content decreases, because of the activity decline of enzymes involved in their production, with a consequent weakening of the intensity of some "green" sensory notes, as depicted in Figure 4 [102-106]. The content of volatile compounds and the stage at which the maximum is achieved are variety-dependent. Gómez-Rico et al. [100] confirmed an increase of C6 compounds in the early stages of ripeness in some Spanish cultivars. Aparicio and Morales [105] described a steady decrease of the level of the volatile compounds, including trans-2-hexenal, from the unripe to the over-ripe stages, except for oil from Coratina fruits that, on the contrary, showed the behaviour observed by the other researchers [102-104]. Angerosa and Basti [102] evidenced the decrease of C6 esters and alcohols from LnA and the increase of hexan-1-ol, a compound considered eliciting a not completely desirable odour $[85,86]$ in the later ripening stages.

The application of multiple regression to the quantitative values of volatile compounds allowed Aparicio and Morales [105] to conclude that the major contributors to the characterization of the ripening process are trans-3-hexen-1-ol, cis-3-hexen-1-ol, trans-2-hexen-1-ol, hexanal and hexyl acetate. The best characterized ripening stage was the unripe one.

\subsubsection{Pedoclimatic Factors}

In the last thirty years many cultivars has been extensively cultivated outside their traditional area, in new producer zones where they were not present at all. This is the case of some varieties that are now cultivated either in areas of the same country where they were not autochthonous (see Northern cv Arbequina in the South of the Spain), or even in countries where olive tree was completely unknown (see Frantoio and Leccino cv in Andalusia, Tunisia, Argentina, South Africa). The use of non-autochthonous cultivars is interesting to evaluate their productivity and adaptation capacity to different agronomical conditions, together with the composition and sensory characteristics of the resulting oils. Temperature, water availability and altitude often are very different from those of the habitual growing areas, and several researches were carried out to elucidate their influence on the physical-chemical and sensory composition of the oils.

The majority of these investigations were carried out on monovarietal oils: in these studies the ripening stage of fruits and the conditions of oil extraction were made uniform to evidence the influence of environmental factors. 


\section{- $\quad$ Altitude}

Phenolic and volatile compositions are affected by altitude and temperature since these factors modify the enzymatic activities. Issaoui et al. [107] evidenced higher levels of trans-2-hexenal and 1-hexanol in oils from low altitude and high temperature. The greater abundance of cis-3-hexenyl acetate and hexyl acetate, the first associated to green odors and the last described as fruity, pear-like by Bauer et al. [108], seem to characterize the oils from high altitude and low temperature. These results are consistent with those of Vichi et al. [109], who found that levels of hexanal, 1-hexanol, trans-2-hexenal, cis-3-hexenal, cis-3-hexen-1-ol, trans-3-hexen-1-ol, and trans-2-hexen-1-ol showed a strong dependence on geographical origin.

Pedoclimatic conditions seem to influence the contents of some hydrocarbons, that have been indicate as possible markers for the varietal or geographical origin characterization [91,109-111]. In oils from mountain the levels of $\alpha$-copaene, $\alpha$-pinene and trans- $\beta$-ocimene were significantly higher than in oils from low altitude and high temperature $[107,109,112]$. Several studies $[107,113]$ showed a higher total amount of phenolic compounds and o-diphenols in oils from high altitude and low temperature, compared with those from low altitude and high temperature. The changed composition in relation to different environmental conditions affects the sensorial characteristics: oils from mountain elicited more intense notes of fruity and bitterness and pungency than those from fruits grown at sea level [107]; sometimes assessors perceived wood and fig tree attributes, typical of oils with high phenolic concentration in oils from high altitude [113].

- Water stress and irrigation

Olive trees come from regions with limited water resources and are generally grown under rain-fed conditions, but in the last years many new orchards have adopted irrigation techniques to considerably increase fruit yields per hectare and therefore total production of the oil $[114,115]$. Results of an investigation carried out in the climatic conditions of Central Italy gave evidence that the changes in volatile composition due to rainfall were pre-eminent and the rainfall were negatively correlated to some compounds, such as hexanal and isobutyl acetate [116]. These features were confirmed by Gómez-Rico et al. [117], who studied the modification of volatile fraction in oils from Cornicabra and Morisca cultivars grown under different irrigation strategies. They found that in both cultivars, the volatiles mostly affected by the water status of olive trees were hexanal, trans-2-hexenal and hexan-1-ol, which show an inverse relationship with the water stress integral observed in the plants. The concentration of VOOs volatile compounds from a medium-high stressed treatment was clearly lower than that obtained under irrigation strategies. Similar trends in C6 aldehydes and alcohols were reported by other researchers in oils from Cornicabra [118] and Leccino [119] cultivars.

On the other hand, Aparicio and Luna [91] and Gómez-Rico and co-workers [118] evidenced differences in the oil composition and in some sensory characteristics of VOOs from irrigated and rain-fed olive trees. In particular they found a greater phenolic concentration and more intense bitterness and pungency in oils from fruits of rain-fed trees than in those from irrigated trees. A similar behaviour was observed also by other researchers [120-123]. The different total amount of phenolic compounds has been related to the water stress level of olives from rain-fed to irrigation conditions, since the activity of enzymes responsible for phenolic compound synthesis, such as L-phenylalanine ammonia-lyase, is greater under higher water stress conditions [121,124].

The water availability affects not only the total amount of phenolic compounds, but also their composition. In oils from some cultivars, such as Arbequina, Cornicabra, Morisca, Leccino, a great decrease in 3,4-DHPEA-EDA, 3,4-DHPEA-EA and $p$-HPEA-EDA was found, as the water stress of olive trees fall off [52,112,118,119,125-127], probably for a reduced activity of enzymes involved in the phenolics synthesis [121], due to the irrigation. As a consequence of the decrease of 3,4-DHPEA and $p$-HPEA secoiridoid derivatives [118], water volumes affect the oxidative stability [128] and the intensities of bitterness and pungency perceptions, being both tightly connected with the concentrations of phenolics $[4,32,54,129]$. 
A considerable weakening of these sensory notes in oils from irrigated olive trees was observed by several researchers $[117,123,130]$, but their decline in these oils was also accompanied by the weakening of odour notes [117]. Low water levels produced oils that emphasize woody and herbaceous sensory notes and very strong intensities of bitterness and pungency that make these oils poorly attractive for consumers; conversely high irrigation levels lowered oil aroma and considerably reduced bitterness and pungency $[123,125,127,130,131]$.

Medium irrigation levels produced complex oils characterized by several well balanced attributes such as artichoke, grass, green apple, and pleasant intensities of bitter and pungent notes [130]. Therefore, the suitable control of the irrigation levels could be a useful tool to produce oils well appreciated by consumer, being characterized by agreeable intensities of olfactory notes, bitterness and pungency. These findings are of great interest, especially for cultivars characterized by high concentrations of phenolic compounds, such as the Spanish Cornicabra and the Italian Coratina varieties. It should be recommended to grow these cultivars under irrigation regime, since high levels of phenolics may negatively influence the olive oil acceptability. The concentrations of lignans 1-acetoxypinoresinol and pinoresinol are slightly influenced by the irrigation practices and should seem to decrease in oils extracted from fruits of low irrigated treatments $[119,125,127]$.

\subsubsection{Time and Conditions of Preservation of Fruits}

In high quality VOOs, obtained from fruits immediately processed after their harvesting, there is not time for establishing phenomena of degradation and/or fermentation and no effects are observed on the volatile and phenolic composition. Irrational conditions and relatively long times of the olive preservation determine both the decrease of the concentration of volatiles from the LOX pathways and phenolic compounds, and the production of volatile compounds related to off-flavours [62-66], as described above.

\subsection{Technological Factors}

The quality of virgin olive oils is tightly dependent on the process of their extraction from olive pastes, where the enzymatic activities represent the main cause of modification of their both sensory characteristics and antioxidant store. On the basis of the system and the conditions adopted for oil extraction, the various mechanical actions cause, with a different importance, a series of interactions among oily phase, vegetation water and solids in the olive paste. This results in: (1) incomplete recovery of the oil that partly remains into pomaces and partly goes away in the vegetation water; (2) losses of minor compounds; (3) beginning of hydrolytic and oxidative phenomena, which can compromise the oil quality. All the steps of oil extraction can modify the volatile and phenolic fractions: the more critical steps are represented by olive crushing and paste malaxation.

\subsubsection{Crushing}

Olive crushing is performed with stone mill or with hammer crusher. During crushing, when the oil flow from vacuole owing to the cell disruption, several enzymes are activated: their activities result in the hydrolysis of secoiridoid glucosides, with production of corresponding aglycons, and in the activation of the LOX pathways that rapidly give rise to C6 and C5 compounds.

The concentration of phenolic compounds in olive oils is dependent on the activities of native enzymes occurring in the fruits that mainly affect the technological steps of crushing and malaxation $[3,55,132,133]$. The secoiridoid glucosides of olive fruits are hydrophilic compounds and they are not solved into the oil during the extraction process. However, the activation of the endogenous $\beta$-glucosidases during crushing [34,134] allows the production of 3,4-DHPEA-EDA, 3,4-DHPEA-EA and $p$-HPEA-EDA in olive oils; in fact the inactivation of these enzymes in blanched olives before crushing is responsible of the absence of aglycons [34] in the corresponding oils.

While the kind of metallic crusher (hammer or blade crusher) poorly affects the amount and the composition of phenolic compounds, as reported by Servili et al. [133], some difference was 
found in oils obtained with stone mill or with metallic crusher [51]: oils from metallic crusher were more bitter and pungent than those from stone mill. Conversely, the kind of crusher affects the amount of volatile compounds [51] formed during this technological operation as a response to cell disruption. The violence of grinding that characterizes the action of metallic crushers, greater than the one of stone mills, causes an instantaneous rise of the temperature that reduces the activity of HPL. This enzyme, catalyzing the fragmentation of hydroperoxides, plays a crucial role in the formation of volatiles. Its activity has a maximum at temperatures around $15^{\circ} \mathrm{C}$ [72]; beyond this temperature its activity rapidly declines and therefore a lower amount of volatiles is formed when compared with that observed in oils from more soft crushing.

Salas et al. [67], evaluating the impact of the depletion of LOX and HPL on the volatile composition of leaves from potato plants, evidenced a severe decrease in the amount of volatiles produced by the leaves and in the intensity of their aroma, confirming the crucial role played by HPL in the production of $\mathrm{C} 6$ compounds responsible for green attributes.

Angerosa and Di Giacinto [51] compared volatile fraction of oils obtained by using stone mill and disc metallic crusher. They concluded that a greater accumulation of hexanal, trans-2-hexenal, cis-3-hexen-1-ol is observed by grinding olives with traditional stone mills. In addition oils from stone mill were more aromatic and balanced than those obtained by using the disc crusher. Data are in agreement with results of Servili and co-workers [133]: oils obtained by using the blade crusher show significant increases of $\mathrm{C} 6$ aldehydes and esters and reduction of some alcohols such as 1-hexanol and trans-2-hexen-1-ol with respect to the oil obtained by using the hammer crusher.

Hexanal and trans-2-hexenal are correlated with apple, green, sweet and just cut grass, bitter almond respectively, hexyl acetate and cis-3-hexenyl acetate with sweet, fruity and green banana, green leaves respectively [49], whereas 1-hexanol and trans-2-hexen-1-ol are related to hay-like sensory note [135]. The sensory analysis (Figure 5) confirmed that the violence of crushing has a negative impact on the intensities and on the harmony of sensory notes [51,133].

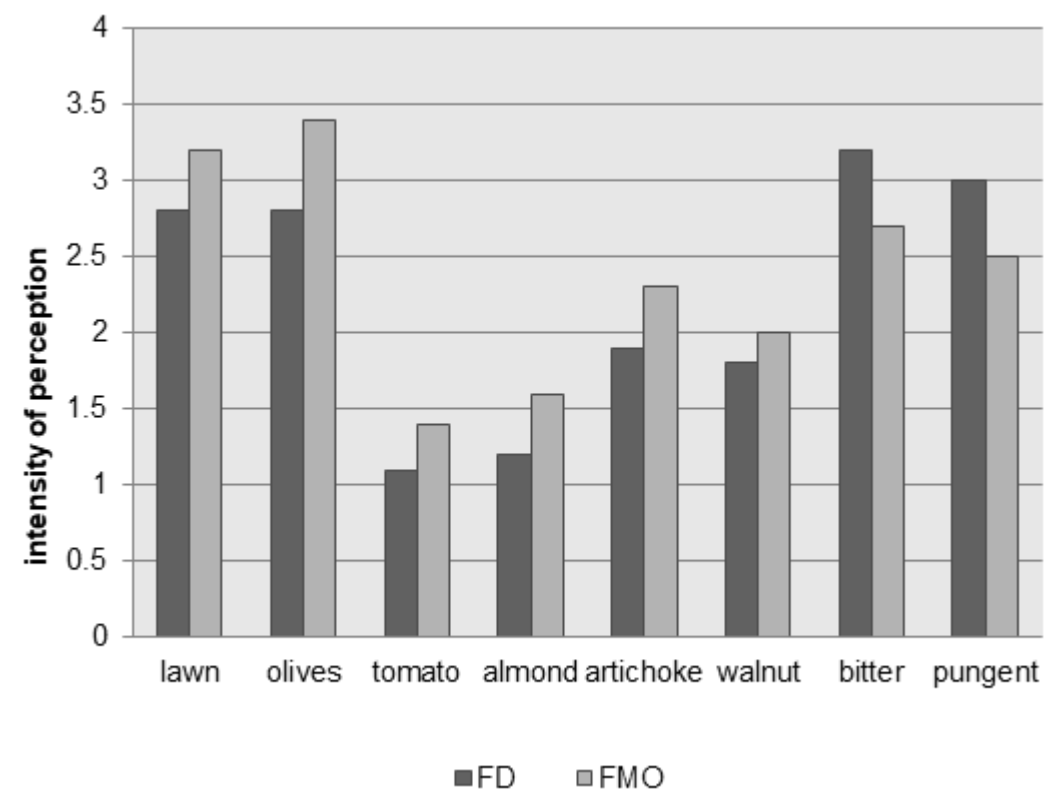

Figure 5. Sensory profiles of oils from fruits of two batches of Provenzale cultivar obtained with the same processing diagram except for crushing. FD = hammer crusher; FMO = stone mill. Figures were obtained on the basis of data collected by our team. Data represent the average of intensities recorded by fully trained tasters in three independent trials. The oils were presented according to an experimental design, which minimized possible biases and carry-over effects. Standard deviation ranged between $\pm 0.2-0.5$. (Source: Authors; unpublished results). 


\section{- Destoning}

Destoning is a new non-conventional olive processing system by which removal of stones before kneading the olive paste increases the quality and sensory properties of VOOs. This improvement arises from the different composition and distribution of endogenous enzymes in olive fruit $[34,136]$ : the partial inhibition of peroxidase (POD) activity, mainly contained in the endosperm of olive, reduces the oxidative degradation of hydrophilic phenols during processing, and increases their content in VVOs. On the other hand destoning does not affect the activity of LOX, mainly contained in the olive pulp tissues, so that the production of volatiles is assured. Removal of the olive stone evidences in the corresponding oils a considerable increases of the phenolic fraction, especially the secoiridoid derivatives such as 3,4-DHPEA-EDA, $p$-HPEA-EDA and 3,4-DHPEA-EA, whereas no significant variations of lignans are observed. Moreover destoning also modifies the volatile profile of VOOs. In oils obtained from destoned olives there is an accumulation of C6 compounds, mainly those arising from LA, compared with oils extracted from whole fruit [136-138]. The high quantity of C6 compounds may be explained by a greater release of membrane-bound enzymes involved in the LOX pathways, owing to a higher degree of cellular damage caused by the grinding of pulp tissue in destoned fruits [137]. Hexanal, reminiscent of green apple or green fruit odour notes [105], gives a great contribution to olive oil flavour because of its low odour threshold [80], and plays an essential role in the formation of majority of green attributes [35].

\subsubsection{Malaxation}

Malaxation consists in a low and continuous kneading of the olive paste and it is an essential operation for achieving high and satisfactory yields of extraction, expecially if the crushing has been performed by using a metallic crusher that causes the oil breakdown into very small droplets. The slow kneading of the olive paste causes the repeated breakdown of lipoproteic membranes, improving the coalescence of the oil droplets, and allows the partition of compounds between the oil and watery phase and vice versa. In the same time, the active endogenous enzymes produce secoiridoid aglycons from corresponding glucosides, oxidized phenolics and volatiles, generating compounds responsible of the flavour.

During malaxation, glucosides degradation gives rise to a significant decrease of their content [139]. The observed losses of secoiridoids derivatives are related to both the greater solubility of phenolic compounds into the aqueous phase [140] and to enzymatic oxidative processes, mediated by polyphenoloxidases (PPO) and peroxidases (POD) [141] occurring in the olive paste. In addition, some interactions between polysaccharides and phenolic compounds may reduce the release of these latter into the oil, contributing to justify the losses due to malaxation step [142].

Time and temperature of processing and oxygen concentration affect the level of phenolic compounds $[130,143,144]$. High temperature more than time of malaxation causes greater losses in phenolic compounds, because of an increase of PPO and POD activities [132,143,145]. The losses of the phenolic fraction have important repercussions, besides on the gustative perceptions, on the oil stability against the oxidation, and therefore on its shelf-life [146].

Malaxation time and temperature should be attentively studied for the oil production from cultivars especially rich in phenolic substances, such as the Italian Coratina and the Spanish Cornicabra, in order to reduce the concentration of phenolic substances without modifying in a considerable way the volatile compound level; the suitable choice of these parameters will weaken the intensity of bitter and pungent attributes, making the oil more agreeable for consumers.

On the contrary, it is important to preserve phenolic compounds in the production of oils from cultivars having a low phenolic content. A partial inhibition of PPO and POD, performed by reducing the $\mathrm{O}_{2}$ level in the paste, that is replacing air with $\mathrm{N}_{2}$ in the headspace of malaxer during processing, minimizes the oxidative degradation of phenolic compounds determining the strong increase of their content in the oil $[34,139,147,148]$ with significant repercussion on its sensory and healthy qualities. A research carried out modifying the Time of Exposure of Olive Paste to Air Contact (TEOPAC), with 
the aim to optimize the malaxation operative conditions in the extraction of Frantoio and Moraiolo oils, evidenced the deleterious effect of high temperatures on the oil quality, according to results of other researchers $[132,143,149,150]$.

Higher amount of phenolic compounds are detected in oils from malaxed destoned pastes than those of oils from integral ones. This feature is explained by a reduced activity of peroxidases (POD), partially eliminated being mainly contained in the olive seed [151]. Moreover this increase could be also dependent on the greater extraction of phenolic compounds due to minute shapes of the olive paste. Volatile compounds, in addition to phenolic ones, are affected by malaxation, because of the activities of enzymes of LOX pathways during the kneading of the olive paste.

Consumers like almost all aroma descriptors qualified with the adjective green $[18,19]$ and therefore the presence of volatiles responsible for pleasant sensory perceptions should be promoted. The ratio among volatiles in the final product is only modified by changing temperature and time of malaxation. Prolonged times increase yields, but promote the accumulation of C6 alcohols and aldehydes, especially hexanal. But long times, in addition to the reduction of phenolic compounds, cause the loss of C6 esters and the increase of C6 alcohols [143], included hexan-1-ol and trans-2-hexen-1-ol, related to not completely agreeable perceptions [86]. However the malaxation temperature has the most important effect on the olive oil volatile composition. High temperatures, in addition to the loss of phenolic compounds, have as a consequence the reduction of the amount of all volatile compounds, especially of cis-3-hexen-1-ol and C6 esters, because of the partial inactivation of HPL [150]. Moreover high temperatures promote the production of trans-2-hexen-1-ol, a volatile characterized by a green smelling and an astringent bitter tasting, the latter being an undesirable sensory perception for potential consumers [18].

Prolonged times, and more heavily, high temperatures cause the increase of branched aldehydes, quite low in high quality VOOs, but without accumulation of corresponding alcohols [143] correlated with "fusty" defect $[62,66]$.

In general, the highest concentrations of aldehydes are measured when malaxing time is shorter, the production of alcohols is promoted at high temperature $\left(35^{\circ} \mathrm{C}\right)$, and the concentration of esters is higher at low temperature $\left(25^{\circ} \mathrm{C}\right)$. Malaxing at high temperatures $\left(\geq 35^{\circ} \mathrm{C}\right)$ promoted formation of green volatiles responsible for undesirable sensory perceptions, whereas low temperatures $\left(\leq 25^{\circ} \mathrm{C}\right)$ favoured production of desirable green sensory perceptions [149]. The same conclusions were achieved by Kalua et al. [144]. The use of an inert gas in the headspace of malaxer does not significantly affect the production of volatile compounds [141].

\subsubsection{Oil Extraction}

VOOs are usually obtained by means of pressure and centrifugation systems. Such separation systems differ not only for the physical forces involved in the oil separation, but also in the amount of water used in the process. Generally pressure does not require any addition of water, whereas centrifugation system needs more or less variable amounts of water to allow the separation of the oil from the olive paste. The added water, modifying the original partition equilibria between oil and water present in the olive paste, affects the chemical composition of the oil and, as a consequence, its sensory and healthy characteristics $[152,153]$. These partition phenomena are of particular importance for the phenolic fraction, essentially formed by hydrophilic compounds.

Phenolics concentration of oils obtained by means of three-phase centrifugation is significantly lower than their level in oils extracted by pressure. In fact the traditional centrifugation needs the addition of a considerable amount of lukewarm water (40-60 L/100 kg of olives) before the centrifugation, to reduce the viscosity of olive pastes. The loss in phenolic compounds extracted by such system, due to a modified distribution for both a dilution effect and a new partition equilibrium [152-155], has significant repercussions on the induction time and therefore on the shelf-life of VOOs. The sensory analysis highlights a weakening of bitter and pungent attributes as a consequence of the reduced levels of secoiridoids. Moreover, the addition of lukewarm water 
can explain the decrease of some volatiles, such as hexan-1-ol and trans-2-hexen-1-ol, with respect to oils separated by pressure $[156,157]$. The adoption of centrifugation systems requiring no addition of water (two-phase decanters) or needing small volumes of water, known as water saving decanters (0-30 L/100 kg of olive paste), allows to obtain oils richer in hydrophilic phenols than those obtained by the traditional three-phases centrifuges [48,152,158-162]. Less important changes have been found in volatile composition of oil from two and three phase decanters, due to a lower water solubility of these compounds when compared with phenolics [55]. At sensory levels these oils are more aromatic and more bitter and pungent than those obtained by traditional centrifugation.

\section{Varietal Characterization}

Monovarietal olive oils have some specific characteristics related to the olive variety from which they are obtained. DNA markers have been used to identify cultivars. Montalegre et al. [162] have recently published an extensive review. Food DNA analysis may represent an attractive and alternative choice to the more classical analytical methods, because DNA provides an opportunity for direct comparison of different genetic material [163-167]. However, Claros et al. [168] showed that soil and climate have significant influence on cultivar differentiation during the years and in addition there is evidence that the genetic diversity of olive cultivars is strongly dependent on the region and country of origin [169]. Since the discovery of amplifiable DNA from olive oil, different genetic markers, generally fragments of DNA or specific sequences of DNA bases or nucleotides, have been used to recognize the cultivar employed for oil production [163,165,169-171]. The assignment of the cultivar is based on the comparation of genetic markers extracted from olive oil, suitably amplified, with those obtained from olive leaves. As an example, by using genetic markers, Breton et al. [169] identified 66 cultivars from their leaves and then they proposed the use of their database for cultivar identification of monovarietal oils and blended commodities. Recently, Consolandi et al. [172] proved that genetic markers are able to differentiate 49 cultivars, the most common of the Mediterranean basin. In spite of some successes in varietal characterization, ascribable to adoption of genetic markers having a great discriminatory power, this approach shows some limitations due to the difficult extraction of genetic material in sufficient quantity and high quality from oils, since oil DNA is highly degraded. Moreover the reproducibility of the amplification markers depends on the quality of the recovered DNA.

Another approach to achieve the differentiation among olive oils, according to the olive variety, is represented by the use of compositional markers. They are affected by the environmental or technical conditions, and this makes difficult the interpretation of the results obtained. They have been differentiated in major components (fatty acids and triglycerides) and minor components (sterols, phenolic compounds, volatile compounds, pigments, hydrocarbons, and tocopherols), according to their presence in olive oils. Many authors claim that the VOO authentication is possible in relation to cultivar, geographic area [173-175], extraction methodologies [149,176,177] by using compositional markers. However, the dependence of the level of many chemical compounds from agronomic and technological factors does not allow to achieve the characterization on the basis of the simple observation of data related to some fractions of VOO composition. Therefore, for the VOO characterization, a great number of variables are needed and data have to be analyzed by statistic techniques or artificial intelligence algorithms. In the application of these statistic methodologies it should be considered the removal of redundant information and the selection of artefacts that can lead to wrong conclusions. In addition, the problem of the characterization is complicated by the fact that data reported in literature are often obtained by using different analytical methodologies and lump them together for characterization. Fatty acids and triacylglycerols, the major components, are the fractions that were mainly used for the varietal characterization of VOOs [161,178-185].

Varietal characterization was also carried out by analyzing only one class of minor compounds [111,175,186-194]. Other researchers used more classes to achieve the varietal characterization [38,84,110,195-202]. In a recent investigation [68] volatiles were used for the characterization of oils from 39 cultivars, native of several producer countries and all grown in 
the same botanical garden. Oils were obtained from fruits harvested at the same ripening degree, processed with the same system and in the same operative conditions. Therefore, as there were no external variables that might unequally affect the enzyme activity of a particular variety, the differences observed in the volatile concentration are related to the variety. Authors first differentiated cultivars according to the content of total volatile compounds, hydrocarbons, aldehydes, alcohols, ketones and esters. A more profound analysis was carried out on C6 compounds because of their importance as green attributes contributors. The application of a cluster analysis to data of $\mathrm{C} 6$ compounds gave pieces of evidence of some similarities among the 39 cultivars. Two main groups, in their turn divided in two groups each one, appeared in the dendrogram, so that there were four groups all formed by varieties of different geographical origin (Table 3).

The contribution of volatiles to aroma of the monovarietal oils is different: Luna and co-workers [68] found that thirteen volatiles did not contribute at all because their odour activity values were lower than 1.0, thirteen of them contributed only for a certain number of varieties and only seven concurred to the sensory profile of all cultivars.

The application of solid phase micro-extraction (SPME) to the analysis of VOOs headspace [109] allowed the detection of significant differences in the proportion of $\mathrm{C} 6$ esters, trans-2-hexenal, trans-2-hexen-1-ol and total amount of metabolites from LnA in monovarietal oils obtained from two different areas of Northern Italy. No differences were observed for C 5 compounds with respect to the cultivar. Moreover authors gave emphasis to the great differences found in the content of $\alpha$-copaene, $\alpha$-farnesene, and hydrocarbons with $>20$ carbon atoms [111]. These differences prove that hydrocarbons can be possible markers for varietal characterization of VOOs, as suggested by other researchers [91,110,111].

Table 3. Cultivars belonging to the four groups evidenced by HCA, and elements they shared.

\begin{tabular}{|c|c|c|c|}
\hline Group & Subgroup & Cultivars & Elements Shared \\
\hline 1 & a & $\begin{array}{l}\text { Arbequina, Coratina, Cima di Bitonto, Chemlal of } \\
\text { Kabylie, Frantoio, Manzanilla, Manzanillo } \\
\text { Cordobe's, Mastoides, Moraiolo, Morruda, Negro, } \\
\text { Nevado, Nisjot, Santa Caterina, Konservalia }\end{array}$ & $\begin{array}{l}\text { high content of trans-2-hexenal; mean } \\
\text { content of alcohols and esters; low } \\
\text { concentration of hexanal }\end{array}$ \\
\hline 1 & $\mathrm{~b}$ & Leccino, Lechín, Megaritiki, Ogghiaredda & $\begin{array}{l}\text { high content of trans-2-hexenal; low } \\
\text { concentration of alcohols; high } \\
\text { concentration of esters; concentrations of } \\
\text { hexanal and alcohols similar }\end{array}$ \\
\hline 2 & a & $\begin{array}{l}\text { Cornicabra, Empeltre, Hojiblanca, Imperial, Picual, } \\
\text { Memecik, Picholine Marrocaine, Sourani }\end{array}$ & $\begin{array}{l}\text { high concentrations of hexan-1-ol and } \\
\text { cis-3-hexen-1-ol; very low concentrations of } \\
\text { trans-2-hexenal and esters; hexanal } \\
\text { concentration higher than trans-2-hexenal }\end{array}$ \\
\hline 2 & $\mathrm{~b}$ & $\begin{array}{l}\text { Adramytini, Cañivano, Chami, Chetoui, Chorruo, } \\
\text { Koroneiki, Nevadillo, Picudo, Redondilla, Tsounati, } \\
\text { Verdial de Huévar, Zaity }\end{array}$ & $\begin{array}{l}\text { high content of trans-2-hexenal and hexanal, } \\
\text { mean content of alcohols; low } \\
\text { concentration of and esters }\end{array}$ \\
\hline
\end{tabular}

Considerable differences were found in the total amount of volatile compounds, alcohols, aldehydes, ketones, and C6 and C5 compounds of oils obtained from fruits of 18 cultivars grown in the same orchard on the western coast of the Garda Lake (Northern Italy) [203]. On the basis of the differences in volatile compositions and sensory profiles, some of the varieties could be differentiated. Headspace-mass spectrometry (HS-MS) methodology was used to characterize varieties [201,204]; data obtained from this procedure need to be processed by statistical procedures and allow to predict the assignation of monovarietal oils, according to olive varieties and geographical origins, correctly classifying ca. $87 \%$ of samples [204].

The different composition in phenolic and volatile compounds from LOX pathway, perceived by consumers as different sensory profiles (Figure 6), can be a useful tool for the varietal characterization. In particular, volatiles arising from LnA LOX pathway have been proposed for the varietal characterization of oils from 20 cultivars [205,206]. 
The varietal characterization can be made through these metabolites, according to an approach that takes into account the different store of enzymes involved in the LOX pathway of the examined cultivars. This metabolic pathway, having linolenic acid as precursor (Figure 2), mainly accumulates trans-2-hexenal and trans-2-hexen-1-ol, owing to the isomerisation of cis-3-hexenal (A branch), and cis-3-hexen-1-ol and cis-3-hexenyl acetate, for subsequent enzymatic reduction and esterification of cis-3-hexenal (B branch), and involves several enzymes.

The amount of each enzyme is strongly dependent of the enzymatic store of each cultivar, as it is proved by the percent of the corresponding accumulation products (Table 4). The sum of amount of all mentioned metabolites represents the amount of their common precursor cis-3-hexenal that, only to a very small extent, does not undergo the activities of isomerase and in some cultivars of alcohol dehydrogenase.

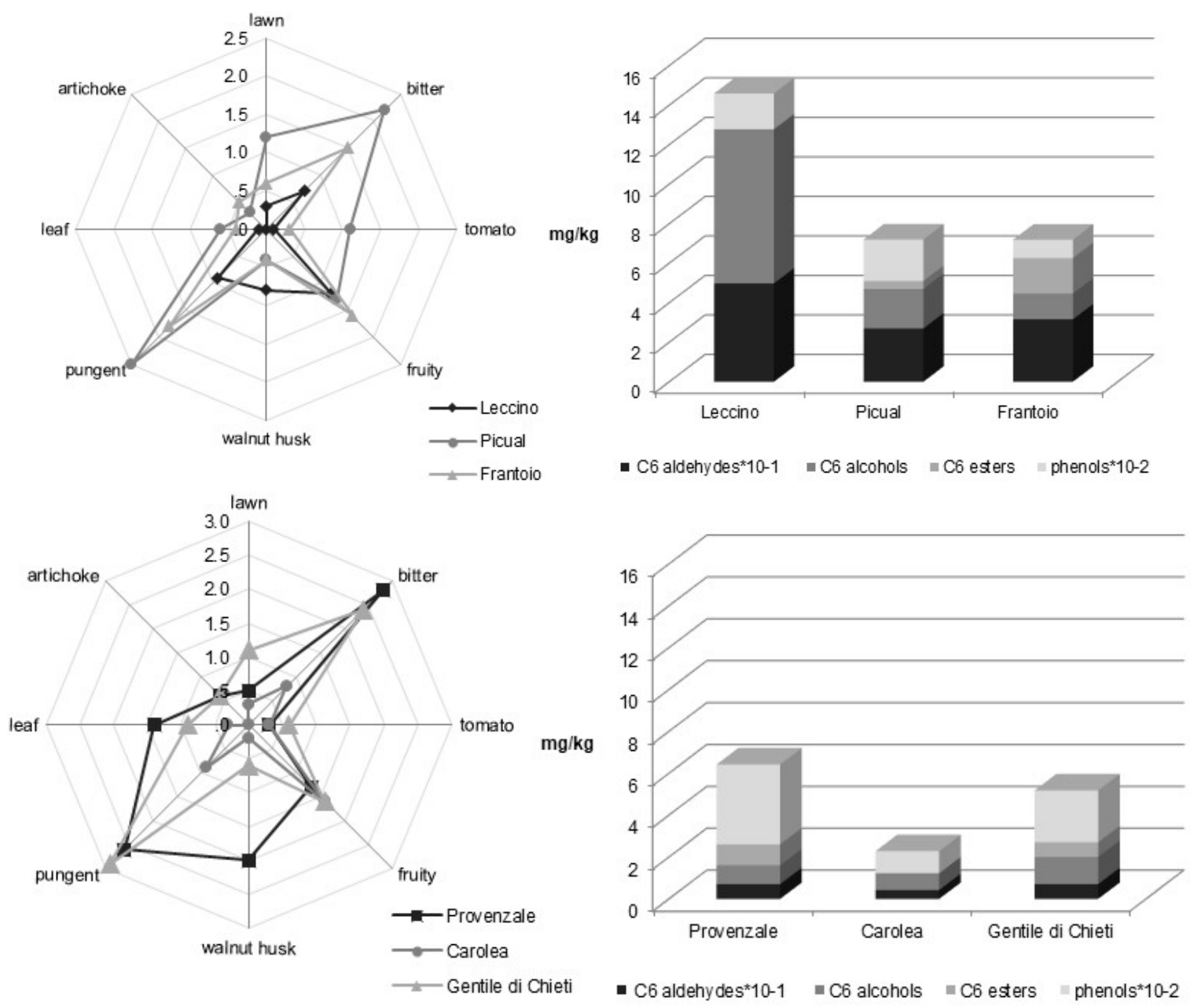

Figure 6. Sensory profiles and concentrations in C6 aldehydes, C6 alcohols and C6 esters and total amount of phenolic compounds of some monovarietal virgin olive oils obtained from fruits harvested at the same ripening degree and processed in the same operative conditions. (Source: Authors; unpublished results).

In Table 4 the amount of trans-2-hexenal includes also the very small amount of cis-3-hexenal since in our gas chromatographic conditions the separation of the two compounds was not complete, because their retention time are very close. The accumulation of trans-2-hexenal in all cultivars, except for Moraiolo, evidences that the isomerisation of cis-3-hexenal is the dominant process. However, the different amounts of trans-2-hexen-1-ol (more than 5\%) in some cultivars (Leccino, 
Dritta, Bosana, Meski, Chetoui) prove a reasonable activity of alcohol dehydrogenases in the reduction of trans-2-hexenal, connected with a fair amount of this enzyme in their genetic store.

$B$ branch is active in different way in many of the cultivars examined, namely Carolea, Bosana, Provenzale, Nocellara del Belice, Gentile di Chieti, Maurino, Koroneiki, Pisciottana, Chetoui, Moraiolo. Among them, only Bosana shows a negligible activity of alcohol dehydrogenases and some activity of alcohol acetyl transferases, owing to the accumulation of $5.2 \%$ of cis-3-hexenyl acetate. In all the other varieties tested, the activity of enzymatic reduction of cis-3-hexenal is the most important process of $\mathrm{B}$ branch. This last is especially important in Moraiolo, Pisciottana and Maurino, since cis-3-hexen-1-ol ranges from 42.4 in Moraiolo to 32.9 in Pisciottana and 20.9 in Maurino, respectively. High levels of alcohol acetyl transferases characterize Koroneiki, Provenzale and Pisciottana.

A branch is the only active in Mastoidis, Coratina, Frantoio, Chemlali, Taggiasca, Canino, and Picual, proving that the activity of isomerase is dominant. The content of trans-2-hexenal differentiates the cultivars. However, Mastoidis and Taggiasca show similar content of trans-2-hexenal. The percent of cis-3-hexen-1-ol and cis-3-hexenyl acetate in Taggiasca indicate some activity of enzymes of B branch, practically absent in Mastoidis cultivar. Picual is characterized by some activity of ADH of B branch, proved by a 5\% of cis-3-hexen-1-ol. Oils from Leccino are characterized only by high activity of isomerases and by a fair activity of ADHs in A branch. Dritta and Bosana, having similar contents of trans-2-hexenal and trans-2-hexen-1-ol, are differentiated by a more important activity of alcohol acetyl transferases in Bosana, proved by the accumulation of a $5 \%$ of cis-3-hexenyl acetate.

Both A and B branches are active in oils from Provenzale, Nocellara del Belice, Gentile di Chieti and Maurino. In all these cultivars alcohol dehydrogenases in A branch are practically absent, whereas are active those of $\mathrm{B}$ branch that cause the accumulation of cis-3-hexen-1-ol. The percent of this metabolite, ranging from about $10 \%$ up to $20 \%$, differentiates the cultivars. In addition, Provenzale is characterized by a considerable activity of alcohol acetyl transferases that is negligible in Maurino, whereas play an important role in Koroneiki, Pisciottana, Moraiolo and Chetoui. Therefore it possible to differentiate all cultivars according to the activities of enzymes involved in A and B branches.

Table 4. trans-2-Hexenal as $\mathrm{mg} / \mathrm{kg}$, and percent distribution of the main metabolites coming from $\mathrm{LnA}$ oxidation in some extra virgin monovarietal olive oils. Results are expressed as mean of three samples of each monovarietal olive oil. (Source: the authors, unpublished results).

\begin{tabular}{|c|c|c|c|c|c|}
\hline Cultivar & $\begin{array}{l}\text { trans-2-Hexenal } \\
(\mathrm{mg} / \mathrm{kg})\end{array}$ & $\%$ trans-2-Hexenal & $\%$ trans-2-Hexen $1-o l$ & \% cis-3-Hexen-1-ol & $\begin{array}{c}\% \text { cis-3-Hexenyl } \\
\text { Acetate }\end{array}$ \\
\hline Mastoidis & 17.1 & 99.4 & 0.1 & 0.5 & 0.0 \\
\hline Coratina & 43.5 & 97.8 & 1.5 & 0.7 & 0.0 \\
\hline Frantoio & 53.4 & 96.6 & 1.2 & 0.7 & 1.5 \\
\hline Chemlali & 14.7 & 95.6 & 1.5 & 1.9 & 1.1 \\
\hline Taggiasca & 17.2 & 94.9 & 1.6 & 1.6 & 1.9 \\
\hline Canino & 30.3 & 94.8 & 2.8 & 2.2 & 0.2 \\
\hline Picual & 23.2 & 92.6 & 1.2 & 5.0 & 1.2 \\
\hline Leccino & 47.3 & 89.0 & 10.1 & 0.9 & 0.0 \\
\hline Dritta & 11.4 & 84.5 & 10.9 & 1.5 & 3.1 \\
\hline Carolea & 7.4 & 83.4 & 2.2 & 14.4 & 0.0 \\
\hline Bosana & 12.1 & 82.7 & 10.1 & 2.0 & 5.2 \\
\hline Provenzale & 5.7 & 79.4 & 1.4 & 9.6 & 9.6 \\
\hline $\begin{array}{l}\text { Nocellara } \\
\text { del Belice }\end{array}$ & 6.8 & 78.4 & 1.1 & 15.8 & 5.0 \\
\hline $\begin{array}{l}\text { Gentile di } \\
\text { Chieti }\end{array}$ & 6.5 & 75.1 & 2.3 & 18.1 & 4.5 \\
\hline Maurino & 6.3 & 74.4 & 2.3 & 20.9 & 2.4 \\
\hline Meski & 6.2 & 61.3 & 37.8 & 1.0 & 0.0 \\
\hline Koroneiki & 4.6 & 58.7 & 3.8 & 16.3 & 21.3 \\
\hline Pisciottana & 1.1 & 52.6 & 4.7 & 32.9 & 9.9 \\
\hline Chetoui & 3.1 & 49.5 & 27.8 & 17.0 & 5.6 \\
\hline Moraiolo & 1.8 & 45.6 & 5.0 & 42.4 & 7.0 \\
\hline
\end{tabular}


Some investigations carried out on oils from Leccino, Coratina and Picual varieties, grown in the botanical garden in two different olive crops from fruits sampled at the same ripening degree and processed in the same conditions, proved that such distribution is the same over the production crop, even if the climatic conditions were very different [206]. On the other hand the same distribution was observed regardless of where the fruit was grown when the fruits show the same ripening degree and are processed in the same conditions: the same results were obtained for oils from Koroneiki and Picual cultivars grown in Central Italy (Pescara) and in Greece (Crete) [206]. Moreover it has been proved that C6 distribution is stable during the ripening process from the half-cherry stage to the black one that is from when the final oil content is reached on. This means its independency from the ripening degree of fruits at least in the usual harvesting time [102]. The independence from where the fruit is grown, the year variability and the ripening degree of olives makes very interesting this approach for varietal characterization and for the control of truthfulness of the cultivar stated on the label. The method is closely dependent on genetic factors, fast, based on a simple head-space analysis and could allow to identify several cultivars, without any application of statistical procedures. The different compositions in volatile compounds, in addition to different content in phenolic compounds, are perceived by consumer as different sensory profiles, as shown in Figure 6.

\section{Conclusions}

Nowadays there is an increasing attention to food. Consumers address their choice to food having special sensory characteristics and able to supply basic nutrients, to improve physical and mental health and to reduce the risk of the most common diseases. High quality VOOs meet all these requirements, being rich in antioxidant compounds having the requested beneficial activities and possessing sensory characteristics that greatly improve the acceptability of food. Sensory profiles of monovarietal VOOs represent an important element able to characterize and differentiate them and, actually, their productions is constantly increasing. Therefore, the main goal of the oil production is to preserve all compounds responsible for sensory notes. The knowledge of the profile of volatiles and phenolics that characterize oil obtained by fruit of a cultivar is, in our opinion, of major importance since it conditions the choice of several parameters affecting the quality of the resulting oil. To achieve the result of an oil with balanced sensory characteristics and highly appreciated by consumers, it is necessary to choose in an appropriate manner factors such as the harvesting time of fruits, the possible amount of irrigation water, the type of system used for the oil extraction, especially the kind of crusher, all greatly dependent by the cultivars.

Acknowledgments: This work was supported by University "G. d'Annunzio" of Chieti-Pescara (MIUR 2016, ex $60 \%$ Grant).

Conflicts of Interest: The authors declare no conflict of interest.

\section{References}

1. Angerosa, F.; Campestre, C.; Giansante, L. Analysis and authentication. In Olive Oil: Chemistry and Technology, 2nd ed.; Dimitrios, B., Ed.; AOCS Press: Champaign, IL, USA, 2006; pp. 113-172. ISBN 978-1-89-399788-2.

2. Angerosa, F.; Campestre, C. Sensory Quality: Methodologies and Applications. In Handbook of Olive Oil-Analysis and Properties; Aparicio, R., Harwood, J., Eds.; Springer: New York, NY, USA, 2013; pp. 523-560. [CrossRef]

3. Angerosa, F. Sensory quality of olive oils. In Handbook of Olive Oil. Analysis and Properties; Harwood, J., Aparicio, R., Eds.; Aspen Publishers Inc.: Gaithersburg, MD, USA, 2000; pp. 355-392. [CrossRef]

4. Baldioli, M.; Servili, M.; Perretti, G.; Montedoro, G.F. Antioxidant activity of tocopherols and phenolic compounds of virgin olive oil. J. Am. Oil Chem. Soc. 1996, 73, 1589-1593. [CrossRef]

5. Boskou, D.; Tsimidou, M.; Blekas, G. Polar phenolic compounds. In Olive Oil: Chemistry and Technology, 2nd ed.; Dimitrios, B., Ed.; AOCS Press: Champaign, IL, USA, 2006; pp. 73-92. [CrossRef] 
6. Bulotta, S.; Celano, M.; Lepore, S.M.; Montalcini, T.; Pujia, A.; Russo, D. Beneficial effects of the olive oil phenolic components oleuropein and hydroxytyrosol: Focus on protection against cardiovascular and metabolic diseases. J. Transl. Med. 2014, 12, 1-9. [CrossRef] [PubMed]

7. Casaburi, I.; Puoci, F.; Chimento, A.; Sirianni, R.; Ruggiero, C.; Avena, P.; Pezzi, V. Potential of olive oil phenols as chemopreventive and therapeutic agents against cancer: A review of in vitro studies. Mol. Nutr. Food Res. 2013, 57, 71-83. [CrossRef] [PubMed]

8. Covas, M.I.; de la Torre, R.; Fito, M. Virgin olive oil: A key food for cardiovascular risk protection. Br. J. Nutr. 2015, 113, S19-S28. [CrossRef] [PubMed]

9. Nasopoulou, C.; Karantonis, H.C.; Detopoulou, M.; Demopoulos, C.A.; Zabetakis, I. Exploiting the anti-inflammatory properties of olive (Olea europaea) in the sustainable production of functional food and neutraceuticals. Phytochem. Rev. 2014, 13, 445-458. [CrossRef]

10. Pantano, D.; Luccarini, I.; Nardiello, P.; Servili, M.; Stefani, M.; Casamenti, F. Oleuropein aglycone and polyphenols from olive mill waste water ameliorate cognitive deficits and neuropathology. Br. J. Clin. Pharmacol. 2017, 83, 54-62. [CrossRef] [PubMed]

11. Piroddi, M.; Albini, A.; Fabiani, R.; Giovannelli, L.; Luceri, C.; Natella, F.; Rosignoli, P.; Rossi, T.; Taticchi, A.; Servili, M.; et al. Nutrigenomics of extra-virgin olive oil: A review. BioFactors 2017, 43, 17-41. [CrossRef] [PubMed]

12. Servili, M.; Selvaggini, R.; Esposto, S.; Taticchi, A.; Montedoro, G.F.; Morozzi, G. Health and sensory properties of virgin olive oil hydrophilic phenols: Agronomic and technological aspects of production that affect their occurrance in the oil. J. Chromatogr. A 2004, 1054, 113-127. [CrossRef]

13. Servili, M.; Esposto, S.; Fabiani, R.; Urbani, S.; Taticchi, A.; Mariucci, F.; Selvaggini, R.; Montedoro, G.F. Phenolic compounds in olive oils: Antioxidant, heath and organoleptic activities according to their chemical structure. Inflammopharmacology 2009, 17, 76-84. [CrossRef] [PubMed]

14. Shahidi, F.; Wanasundra, P.D. Phenolic antioxidants. Crit. Rev. Food Sci. Nutr. 1992, 32, 67-103. [CrossRef] [PubMed]

15. Tripoli, E.; Giammanco, M.; Tabacchi, G.; Di Majo, D.; Giammanco, S.; La Guardia, M. The phenolic compounds of olive oil: Structure, biological activity and beneficial effects on human health. Nutr. Res. Rev. 2005, 18, 98-112. [CrossRef] [PubMed]

16. Vilaplana-Perez, C.; Aunon, D.; Garcia-Flores, L.A.; Gil-Izquierdo, A. Hydroxytyrosol and potential uses in cardiovascular diseases, cancer, and AIDS. Front. Nutr. 2014, 1, 18. [CrossRef] [PubMed]

17. Visioli, F. Olive oil phenolics: Where do we stand? Where should we go? J. Sci. Food Agric. 2012, 92, 2017-2019. [CrossRef] [PubMed]

18. McEwan, J.A. Consumer attitudes and olive oil acceptance: The potential consumer. Grasas y Aceites 1994, 45, 9-15. [CrossRef]

19. Pagliarini, E.; Bertuccioli, M.; Abbà, S. Consumer attitudes and olive oil acceptance: The traditional consumer. Grasas y Aceites 1994, 45, 16-19. [CrossRef]

20. Cicerale, S.; Lucas, L.; Keast, R. Biological activities of phenolic compounds present in virgin olive oil. Int. J. Mol. Sci. 2010, 11, 458-479. [CrossRef] [PubMed]

21. Visioli, F.; Galli, C.; Plasmati, E.; Viappiani, S.; Hernandez, A.; Colombo, C.; Sala, A. Olive phenol hydroxytyrosol prevents passive smoking-induced oxidative stress. Circulation 2000, 102, 2169-2171. [CrossRef] [PubMed]

22. Owen, R.; Giacosa, A.; Hull, W.; Haubner, R.; Würtele, G.; Spiegelhalder, B.; Bartsch, H. Olive-oil consumption and health: The possible role of antioxidants. Lancet Oncol. 2000, 1, 107-112. [CrossRef]

23. Martin-Pelaez, S.; Covas, M.I.; Fito, M.; Kusar, A.; Pravst, I. Health effects of olive oil polyphenols: Recent advances and possibilities for the use of health claims. Mol. Nutr. Food Res. 2013, 57, 760-771. [CrossRef] [PubMed]

24. Tuck, K.L.; Hayball, P.J. Major phenolic compounds in olive oil: Metabolism and health effects. J. Nutr. Biochem. 2002, 13, 636-644. [CrossRef]

25. Visioli, F.; Galli, C. Olive oil phenols and their potential effects on human health. J. Agric. Food Chem. 1998, 46, 4292-4296. [CrossRef]

26. Cinquanta, L.; Esti, M.; La Notte, E. Evolution of phenolic compounds in virgin olive oil during storage. J. Am. Oil Chem. Soc. 1997, 74, 1259-1264. [CrossRef] 
27. Cinquanta, L.; Esti, M.; Di Matteo, M. Oxidative stability of virgin olive oils. J. Am. Oil Chem. Soc. 2001, 78, 1197-1202. [CrossRef]

28. Esposto, S.; Taticchi, A.; Urbani, S.; Selvaggini, R.; Veneziani, G.; Di Maio, I.; Sordini, B.; Servili, M. Effect of light exposure on the quality of extra virgin olive oils according to their chemical composition. Food Chem. 2017, 229, 726-733. [CrossRef] [PubMed]

29. Ottaviani, M.F.; Spallaci, M.; Cangiotti, M.; Bacchiocca, M.; Ninfali, P. Electron paramagnetic resonance investigations of free radicals in extra virgin olive oils. J. Agric. Food Chem. 2001, 49, 3691-3696. [CrossRef] [PubMed]

30. Psomiadou, E.; Tsimidou, M. Stability of virgin olive oil: 1. Autoxidation studies. J. Agric. Food Chem. 2002, 50, 716-721. [CrossRef] [PubMed]

31. Velasco, J.; Dobarganes, C. Oxidative stability of virgin olive oil. Eur. J. Lipid Sci. Technol. 2002, 104, 661-676. [CrossRef]

32. Andrewes, P.; Busch, J.L.H.C.; de Joode, T.; Groenewegen, A.; Alexandre, H. Sensory properties of virgin olive oil polyphenols: Identification of deacetoxy-ligstroside aglycon as a key contributor to pungency. J. Agric. Food Chem. 2003, 51, 1415-1420. [CrossRef] [PubMed]

33. Gutiérrez-Rosales, F.; Ríos, J.J.; Gómez-Rey, M.L. Main polyphenols in the bitter taste of virgin olive oil. Structural confirmation by on-line high-performance liquid chromatography electrospray ionization mass spectrometry. J. Agric. Food Chem. 2003, 51, 6021-6025. [CrossRef] [PubMed]

34. Servili, M.; Montedoro, G.F. Contribution of phenolic compounds to virgin olive oil quality. Eur. J. Lipid Sci. Technol. 2002, 104, 602-613. [CrossRef]

35. Angerosa, F.; Mostallino, R.; Basti, C.; Vito, R. Virgin olive oil odour notes: Their relationships with volatile compounds from lipoxygenase pathways and secoiridoid compounds. Food Chem. 2000, 68, 283-287. [CrossRef]

36. Favati, E.; Caporale, G.; Bertuccioli, M. Rapid determination of phenol content in extra virgin olive oil. Grasas y Aceites 1994, 45, 68-70. [CrossRef]

37. Gutiérrez Rosales, F.; Perdiguero, S.; Gutiérrez, R.; Olias, J.M. Evaluation of the bitter taste in virgin olive oil. J. Am. Oil Chem. Soc. 1992, 69, 394-395. [CrossRef]

38. Aparicio, R.; Morales, M.T.; Alonso, M.V. Authentication of European virgin olive oils by their chemical compounds, sensory attributes, and consumers' attitudes. J. Agric. Food Chem. 1997, 45, 1076-1083. [CrossRef]

39. Caporale, G.; Policastro, S.; Carlucci, A.; Monteleone, E. Consumer expectations for sensory properties in virgin olive oils. Food Qual. Prefer. 2006, 17, 116-125. [CrossRef]

40. Monteleone, E.; Caporale, G.; Carlucci, A.; Pagliarini, E. Optimisation of extra virgin olive oil quality. J. Sci. Food Agric. 1999, 77, 31-37. [CrossRef]

41. Angerosa, F.; d'Alessandro, N.; Corana, F.; Mellerio, G. Characterization of phenolic and secoiridoid aglycons present in virgin olive oil by gas chromatography-chemical ionization mass spectrometry. J. Agric. Food Chem. 1995, 43, 1802-1807. [CrossRef]

42. Montedoro, G.F.; Servili, M.; Baldioli, M.; Miniati, E. Simple and hydrolizable compounds in virgin olive oil. 1. Their extraction, separation, and quantitative and semiquantitative evaluation by HPLC. J. Agric. Food Chem. 1992, 40, 1571-1576. [CrossRef]

43. Montedoro, G.F.; Servili, M.; Baldioli, M.; Miniati, E. Simple and hydrolizable compounds in virgin olive oil. Note 2: Initial characterization of the hydrolizable fraction. J. Agric. Food Chem. 1992, 40, 1577-1580. [CrossRef]

44. Montedoro, G.F.; Servili, M.; Baldioli, M.; Selvaggini, R.; Miniati, E.; Macchioni, A. Simple and hydrolizable compounds in virgin olive oil. Note 3: Spectroscopic characterization of the secoiridoid derivatives. J. Agric. Food Chem. 1993, 41, 2228-2234. [CrossRef]

45. Perri, E.; Raffaelli, A.; Sindona, G. Quantitation of Oleuropein in Virgin Olive Oil by Ionspray Mass Spectrometry-Selected Reaction Monitoring. J. Agric. Food Chem. 1999, 47, 4156-4160. [CrossRef] [PubMed]

46. Brenes, M.; Hidalgo, F.J.; García, A.; Ríos, J.J.; García, P.; Zamora, R.; Garrido, A. Pinoresinol and 1-acetoxypinoresinol, two new phenolic compounds identified in olive oil. J. Am. Oil Chem. Soc. 2000, 77, 715-720. [CrossRef]

47. Owen, R.W.; Mier, W.; Giacosa, A.; Hull, W.E.; Spiegelhalder, B.; Bartsch, H. Identification of lignans as major components in the phenolic fraction of olive oil. Clin. Chem. 2000, 46, 976-988. [PubMed] 
48. García, A.; Brenes, M.; Martínez, F.; Alba, J.; García, P.; Garrido, A. High-performance liquid chromatography evaluation of phenols in virgin olive oil during extraction at laboratory and industrial scale. J. Am. Oil Chem. Soc. 2001, 78, 625-629. [CrossRef]

49. Kiritsakis, A.K. Flavor Components of Olive Oil-A Review. J. Am. Oil Chem. Soc. 1998, 75, 673-681. [CrossRef]

50. Soler-Rivas, C.; Espin, J.C.; Wichers, H.J. Oleuropein and related compounds. A review. J. Sci. Food Agric. 2000, 80, 1013-1023. [CrossRef]

51. Angerosa, F.; Di Giacinto, L. Caratteristiche di qualità dell'olio di oliva vergine in relazione ai metodi di frangitura. Nota II. Riv. Ital. Delle Sostanze Grasse 1995, 72, 1-4.

52. Tovar, M.J.; Motilva, M.J.; Luna, M.; Girona, J.; Romero, M.P. Analytical characteristics of virgin olive oil from young trees (Arbequina cultivar) growing under linear irrigation strategies. J. Am. Oil Chem. Soc. 2001, 78, 843-849. [CrossRef]

53. Beauchamp, G.K.; Keast, R.S.J.; Morel, D.; Lin, J.; Pika, J.; Han, Q.; Lee, C.H.; Smith, A.B.; Breslin, P.A.S. Ibuprofen-like activity in extra-virgin olive oil. Nature 2005, 437, 45-46. [CrossRef] [PubMed]

54. Mateos, R.; Cert, A.; Pérez-Camino, M.C.; García, J.M. Evaluation of virgin olive oil bitterness by quantification of secoiridoid derivatives. J. Am. Oil Chem. Soc. 2004, 81, 71-75. [CrossRef]

55. Angerosa, F.; Servili, M.; Selvaggini, R.; Taticchi, A.; Esposto, S.; Montedoro, G.F. Volatile compounds in virgin olive oil: Occurrence and their relationship with the quality. J. Chromatogr. A 2004, 1054, 17-31. [CrossRef]

56. Kalua, C.M.; Allen, M.S.; Bedgood, D.R., Jr.; Bishop, A.G.; Prenzler, P.D.; Robards, K. Olive oil volatile compounds, flavour development and quality: A critical review. Food Chem. 2007, 100, 273-286. [CrossRef]

57. Angerosa, F. Influence of volatile compounds on virgin olive oil quality evaluated by analytical approaches and sensor panels. Eur. J. Lipid Sci. Technol. 2002, 104, 639-660. [CrossRef]

58. Morales, M.T.; Aparicio, R.; Ríos, J.J. Dynamic headspace gas chromatographic method for determining volatiles in virgin olive oil. J. Chromatogr. A 1994, 668, 455-462. [CrossRef]

59. Vick, B.A.; Zimmermann, D.C. The lipoxygenase pathway. In The Biochemistry of Plants; Stumpf, P.K., Conn, E.E., Eds.; Academic Press: New York, NY, USA, 1987; pp. 53-90.

60. Hatanaka, A. The biogeneration of green odour by green leaves. Phytochemistry 1993, 34, 1201-1218. [CrossRef]

61. Olías, J.M.; Perez, A.G.; Ríos, J.J.; Sanz, L.C. Aroma of virgin olive oil: Biogenesis of the "green" odor notes. J. Agric. Food Chem. 1993, 41, 2368-2373. [CrossRef]

62. Angerosa, F.; Lanza, B.; Marsilio, V. Biogenesis of "fusty" defect in virgin olive oils. Grasas y Aceites 1996, 47, 142-150. [CrossRef]

63. Angerosa, F.; Lanza, B.; Marsilio, V.; Cumitini, S. Olive oil off odour compounds produced by Aspergillus and Penicillium. Acta Hortic. 1999, 474, 695-699. [CrossRef]

64. Aparicio, R.; Rocha, S.M.; Delgadillo, I.; Morales, M.T. Detection of rancid defect in virgin olive oil by the electronic nose. J. Agric. Food Chem. 2000, 48, 853-860. [CrossRef] [PubMed]

65. Morales, M.T.; Luna, G.; Aparicio, R. Sensory and chemical evaluation of winey-vinegary defect in virgin olive oils. Eur. Food Res. Technol. 2000, 211, 222-228. [CrossRef]

66. Morales, M.T.; Luna, G.; Aparicio, R. Comparative study of virgin olive oil sensory defects. Food Chem. 2005, 91, 293-301. [CrossRef]

67. Salas, J.J.; Sánchez, C.; García-González, D.L.; Aparicio, R. Impact of the suppression of lipoxygenase and hydroperoxide lyase on the quality of the green odor in green leaves. J. Agric. Food Chem. 2005, 53, 1648-1655. [CrossRef] [PubMed]

68. Luna, G.; Morales, M.T.; Aparicio, R. Characterisation of 39 varietal virgin olive oils by their volatile compositions. Food Chem. 2006, 98, 243-252. [CrossRef]

69. Angerosa, F.; d'Alessandro, N.; Basti, C.; Vito, R. Biogeneration of volatile compounds in virgin olive oil: Their evolution in relation to malaxation time. J. Agric. Food Chem. 1998, 46, 2940-2944. [CrossRef]

70. Angerosa, F.; Camera, L.; d'Alessandro, N.; Mellerio, G. Characterization of seven new hydrocarbon compounds present in the aroma of virgin olive oils. J. Agric. Food Chem. 1998, 46, 648-653. [CrossRef] [PubMed]

71. Salas, J.J.; Williams, M.; Harwood, J.H.; Sánchez, J. Lipoxygenase activity in olive (Olea europaea) fruit. J. Am. Oil Chem. Soc. 1999, 76, 1163-1168. [CrossRef] 
72. Salas, J.J.; Sánchez, J. Hydroperoxide lyase from olive (Olea europaea) fruit. Plant Sci. 1999, 143, $19-26$. [CrossRef]

73. Salas, J.J.; Sánchez, J. Alcohol dehydrogenases from olive (Olea europaea) fruit. Phytochemistry 1998, 48, 35-40. [CrossRef]

74. Salas, J.J. Characterization of alcohol acyltransferase from olive fruit. J. Agric. Food Chem. 2004, 52, 3155-3158. [CrossRef] [PubMed]

75. Hatanaka, A.; Kajiwara, T.; Horino, H.; Inokuchi, K. Odour-structure relationships in n-hexanols and n-hexenales. Z. Naturforsch. 1992, 47c, 183-189.

76. Pelosi, P. Odorant-binding proteins. Crit. Rev. Biochem. Mol. Biol. 1994, 29, 199-228. [CrossRef] [PubMed]

77. Rossiter, K.J. Structure-odor relationships. Chem. Rev. 1996, 96, 3201-3240. [CrossRef] [PubMed]

78. O'Connell, R.J.; Stevens, D.A.; Akers, R.P.; Coppola, D.M.; Grant, A.J. Individual differences in the quantitative and qualitative responses human subjects to various odours. Chem. Senses 1989, 14, $293-302$. [CrossRef]

79. Guth, H.; Grosch, W. A comparative study of the potent odorants of different virgin olive oils. Fett Wiss. Technol./Fat Sci. Technol. 1991, 93, 335-339. [CrossRef]

80. Guth, H.; Grosch, W. Quantitation of potent odorants of virgin olive oil by stable-isotope dilution assays. J. Am. Oil Chem. Soc. 1993, 70, 513-518. [CrossRef]

81. Breslin, P.A.S. Interactions among salty, sour and bitter compounds. Trends Food Sci. Technol. 1996, 71, 390-399. [CrossRef]

82. Erickson, R.P.; Covey, E. On the singularity of taste sensations: What is a taste primary? Physiol. Behav. 1980, 25, 527-533. [CrossRef]

83. Servili, M.; Conner, J.M.; Piggott, J.R.; Withers, S.J.; Paterson, A. Sensory characterisation of virgin olive oil and relationship with headspace composition. J. Sci. Food Agric. 1995, 67, 61-70. [CrossRef]

84. Morales, M.T.; Alonso, M.V.; Ríos, J.J.; Aparicio, R. Virgin olive oil aroma: Relationship between volatile compounds and sensory attributes by chemometrics. J. Agric. Food Chem. 1995, 43, 2925-2931. [CrossRef]

85. Aparicio, R.; Morales, M.T. Sensory wheels: A statistical technique for comparing QDA panels. Application to virgin olive oil. J. Sci. Food Agric. 1995, 67, 247-257. [CrossRef]

86. Aparicio, R.; Morales, M.T.; Alonso, M.V. Relationship between volatile compounds and sensory attributes of olive oils by the sensory wheel. J. Am. Oil Chem. Soc. 1996, 73, 1253-1264. [CrossRef]

87. Brenes, M.; Garcia, A.; Garcia, P.; Ríos, J.J.; Garrido, A. Phenolic compounds in Spanish oils. J. Agric. Food Chem. 1999, 47, 3535-3540. [CrossRef] [PubMed]

88. Esti, M.; Cinquanta, L.; La Notte, E. Phenolic compounds in different olive varieties. J. Agric. Food Chem. 1998, 46, 32-35. [CrossRef] [PubMed]

89. Pannelli, G.; Servili, M.; Famiani, F.; Montedoro, G.F. Agro-climatic factors and characteristics of the composition of virgin olive oils. Acta Hortic. 1990, 286, 477-480. [CrossRef]

90. Uceda, M.; Hermoso, M.; García-Ortiz, A.; Jimenez, A.; Beltrán, G. Intraspecific variation of oil contents and the characteristics of oils in olive cultivars. Acta Hortic. 1999, 474, 659-662. [CrossRef]

91. Aparicio, R.; Luna, G. Characterization of monovarietal virgin olive oils. Eur. J. Lipid Sci. Technol. 2002, 104, 614-627. [CrossRef]

92. Angerosa, F.; Di Giacinto, L.; d'Alessandro, N. Quantitation of some flavour components of the "green" attributes in virgin olive oils. J. High Resol. Chromatogr. 1997, 20, 507-510. [CrossRef]

93. Connor, D.J.; Fereres, E. The physiology of adaptation and yield expression in olive. Hortic. Rev. 2005, 31, 155-229. [CrossRef]

94. Amiot, M.J.; Fleuriet, A.; Macheix, J.J. Importance and evolution of phenolic compounds in olive during growth and maturation. J. Agric. Food Chem. 1986, 34, 823-826. [CrossRef]

95. Amiot, M.J.; Fleuriet, A.; Macheix, J.J. Accumulation of oleuropein derivatives during olive maturation. Phytochemistry 1989, 28, 67-69. [CrossRef]

96. Rotondi, A.; Bendini, A.; Cerretani, L.; Mari, M.; Lercker, G.; Toschi, T.G. Effect of olive ripening degree on the oxidative stability and organoleptic properties of cv. Nostrana di Brisighella extra virgin olive oil. J. Agric. Food Chem. 2004, 52, 3649-3654. [CrossRef] [PubMed]

97. Ryan, D.; Antolovich, M.; Prenzler, P.; Robards, K.; Lavee, S. Biotransformations of phenolic compounds. Sci. Hortic. 2002, 92, 147-176. [CrossRef] 
98. Baccouri, O.; Cerretani, L.; Bendini, A.; Caboni, M.F.; Zarrouk, M.; Pirrone, L.; Ben Lilled, D.D. Preliminary chemical characterization of Tunisian monovarietal virgin olive oils and comparison with Sicilian ones. Eur. J. Lipid Sci. Technol. 2007, 109, 1208-1217. [CrossRef]

99. Caponio, F.; Gomes, T.; Pasqualone, A. Phenolic compounds in virgin olive oils: Influence of the degree of olive ripeness on organoleptic characteristics and shelf-life. Eur. Food Res. Technol. 2001, 212, 329-333. [CrossRef]

100. Gómez-Rico, A.; Fregapane, G.; Salvador, M.D. Effect of cultivar and ripening on minor components in Spanish olive fruits and their corresponding virgin olive oils. Food Res. Inter. 2008, 41, 433-440. [CrossRef]

101. Limiroli, R.; Consonni, R.; Ottolina, G.; Marsilio, V.; Bianchi, G.; Zetta, L. ${ }^{1} \mathrm{H}$ and ${ }^{13} \mathrm{C}$ NMR characterization of new oleuropein aglycones. J. Chem. Soc. Perk. Trans. 1 1995, 5, 1519-1523. [CrossRef]

102. Angerosa, F; Basti, C. Olive oil volatile compounds from the lipoxygenase pathway in relation to fruit ripeness. Ital. J. Food Sci. 2001, 13, 421-428.

103. Montedoro, G.F.; Bertuccioli, M.; Anichini, F. Aroma analysis of virgin olive oil by head space (volatiles) and extraction technique. In Flavor of Foods and Beverages: Chemistry and Technology; Charalambousand, G., Inglett, G.E., Eds.; Academic Press: New York, NY, USA, 1978; pp. 247-281.

104. Solinas, M.; Marsilio, V.; Angerosa, F. Evoluzione di alcuni componenti dell'aroma degli oli di oliva in relazione al grado di maturazione delle olive. Riv. Ital. Sostanze Gr. 1987, 64, 475-480.

105. Aparicio, R.; Morales, M.T. Characterization of olive ripeness by green aroma compounds of virgin olive oil. J. Agric. Food Chem. 1998, 46, 1116-1122. [CrossRef]

106. Morales, M.T.; Aparicio, R.; Calvente, J.J. Influence of olive ripeness on the concentration of green aroma compounds in virgin olive oil. Flavour Frag. J. 1996, 11, 171-178. [CrossRef]

107. Issaoui, M.; Flamini, G.; Brahmi, F.; Dabbou, S.; Ben Hassine, K.; Taamali, A.; Chehab, H.; Ellouz, M.; Zarrouk, M.; Hammami, M. Effect of the growing area conditions on differentiation between Chemlali and Chétoui olive oils. Food Chem. 2010, 119, 220-225. [CrossRef]

108. Bauer, K.; Garbe, D.; Surburg, H. Common Fragrance and Flavor Materials: Preparation, Properties and Uses, 2nd ed.; VCH Publishers: Weinheim, Germany, 1990; pp. 7-18.

109. Vichi, S.; Pizzale, L.; Conte, L.; Buxaderas, S.; Pez-Tamames, E.L. Solid-Phase Microextraction in the analysis of virgin olive oil volatile fraction: Characterization of virgin olive oils from two distinct geographical areas of Northern Italy. J. Agric. Food Chem. 2003, 51, 6572-6577. [CrossRef] [PubMed]

110. Bortolomeazzi, R.; Berno, P.; Pizzale, L.; Conte, L.S. Sesquiterpene, alkene, and alkane hydrocarbons in virgin olive oils of different varieties and geographical origins. J. Agric. Food Chem. 2001, 49, 3278-3283. [CrossRef] [PubMed]

111. Guinda, A.; Lanzón, A.; Albi, T. Differences in hydrocarbons of virgin olive oils obtained from several olive varieties. J. Agric. Food Chem. 1996, 44, 1723-1726. [CrossRef]

112. Temime, S.B.; Campeol, E.; Cioni, P.L.; Daoud, D.; Zarrouk, M. Irrigation effects on quality, phenolic composition, and selected volatiles of virgin olive oils cv. Leccino. Food Chem. 2006, 99, 315-325. [CrossRef]

113. Aguilera, M.P.; Beltrán, G.; Ortega, D.; Fernández, A.; Jiménez, A.; Uceda, M. Characterisation of virgin olive oil of Italian olive cultivars: 'Frantoio' and 'Leccino', grown in Andalusia. Food Chem. 2005, 89, 387-391. [CrossRef]

114. Beede, R.H.; Goldhamer, D.A. Olive irrigation management. In Olive Production Manual; Ferguson, L., Sibetti, G.S., Martin, G.C., Eds.; University of California: Oakland, CA, USA, 1994; pp. 61-68.

115. Inglese, P.; Barone, E.; Gullo, G. The effect of complementary irrigation on fruit growth, ripening pattern and oil characteristics of olive (Olea europaea L.) cv. Carolea. J. Hortic. Sci. 1996, 71, 257-263. [CrossRef]

116. Pannelli, G.; Servili, M.; Selvaggini, R.; Baldioli, M.; Montedoro, G.F. Effect of agronomic and seasonal factors on olive (Olea europaea L.) production and on the qualitative characteristics of the oil. Acta Hortic. 1994, 356, 239-243. [CrossRef]

117. Gómez-Rico, A.; Salvador, M.D.; Fregapane, G. Virgin olive oil and olive fruit minor constituents as affected by irrigation management based on SWP and TDF as compared to ETc in medium-density young olive orchards (Olea europaea L. cv. Cornicabra and Morisca). Food Res. Int. 2009, 42, 1067-1076. [CrossRef]

118. Gómez-Rico, A.; Salvador, M.D.; La Greca, M.; Fregapane, G. Phenolic and volatile compounds of extra virgin olive oil (Olea europaea L. Cv. Cornicabra) with regard to fruit ripening and irrigation management. J. Agric. Food Chem. 2006, 54, 7130-7136. [CrossRef] [PubMed] 
119. Servili, M.; Esposto, S.; Lodolin, E.; Selvaggini, R.; Taticchi, A.; Urbani, S.; Montedoro, G.F.; Serravalle, M.; Gucci, R. Irrigation effects on quality, phenolic composition, and selected volatiles of virgin olive oils Cv. Leccino. J. Agric. Food Chem. 2007, 55, 6609-6618. [CrossRef] [PubMed]

120. Pannelli, G.; Famiani, F.; Servili, M.; Montedoro, G.F. Agroclimatic factors and characteristics of the compostion of virgin olive oils. Acta Hortic. 1989, 286, 477-480. [CrossRef]

121. Patumi, M.; D’Andria, R.; Fontanazza, G.; Morelli, G.; Giori, P.; Sorrentino, G. Yield and oil quality of intensively trained trees of three cultivars of olive under different irrigation regimes. J. Hortic. Sci. Biotech. 1999, 74, 729-737. [CrossRef]

122. Patumi, M.; D’Andria, R.; Marsilio, G.; Fontanazza, G.; Morelli, G.; Lanza, B. Olive and olive oil quality after intensive monocone olive growing (Olea europaea L.; cv. Kalamata) in different irrigation regimes. Food Chem. 2002, 77, 27-34. [CrossRef]

123. Salas, J.; Pastor, M.; Castro, J.; Vega, V. Irrigation effects on fatty acidic composition, organoleptic characteristics and other quality parameters of virgin olive oils. Grasas y Aceites 1997, 48, 74-82. [CrossRef]

124. Tovar, M.J.; Romero, M.P.J.; Girona, M.J. L-Phenylalanine ammonia-lyase activity and concentration of phenolics in developing fruit of olive tree (Olea europaea L. cv. Arbequina) grown under different irrigation regimes. J. Sci. Food Agric. 2002, 82, 892-898. [CrossRef]

125. Dabbou, S.; Chehab, H.; Faten, B.; Dabbou, S.; Esposto, S.; Selvaggini, R.; Taticchi, A.; Servili, M.; Montedoro, G.F.; Hammami, M. Effect of three irrigation regimes on Arbequina olive oil produced under Tunisian growing conditions. Agric. Water Manag. 2010, 97, 763-768. [CrossRef]

126. D'Andria, R.; Morelli, G.; Martuccio, G.; Fontanazza, G.; Patumi, M. Valutazione della produzione e della qualità dell'olio di giovani piante di olivo allevate con diversi regimi idrici. Italus Hortus 1996, 3, $23-31$.

127. Tovar, M.J.; Motilva, M.J.; Romero, M.P. Changes in the phenolic composition of virgin olive oil from young trees (Olea europaea L. cv. Arbequina) grown under linear irrigation strategies. J. Agric. Food Chem. 2001, 49, 5502-5508. [CrossRef] [PubMed]

128. Gómez-Rico, A.; Salvador, M.D.; Moriana, A.; Pérez, D.; Olmedilla, N.; Ribas, F.; Fregapane, G. Influence of different irrigation strategies in a traditional Cornicabra cv. olive orchard on virgin olive oil composition and quality. Food Chem. 2007, 100, 568-578. [CrossRef]

129. Aparicio, R.; Roda, L.; Albi, M.A.; Gutiérrez, F. Effect of various compounds on virgin olive oil stability measured by Rancimat. J. Agric. Food Chem. 1999, 47, 4150-4155. [CrossRef] [PubMed]

130. Berenguer, M.J.; Vossen, P.M.; Grattan, S.R.; Connell, J.H.; Polito, V.S. Tree irrigation levels for optimum chemical and sensory properties of olive oil. HortScience 2006, 41, 427-432.

131. Tovar, M.J.; Romero, M.P.; Alegre, S.; Girona, J.; Motilva, M.J. Composition and organoleptic characteristics of oil from Arbequina olive (Olea europaea L.) trees under deficit irrigation. J. Sci. Food Agric. 2002, 82, 1755-1763. [CrossRef]

132. Servili, M.; Baldioli, M.; Montedoro, G.F. Phenolic composition of VOO in relationship to some chemical and physical aspects of malaxation. Acta Hortic. 1994, 356, 331-336. [CrossRef]

133. Servili, M.; Piacquadio, P.; De Stefano, G.; Taticchi, A.; Sciancalepore, V. Influence of a new crushing technique on the composition of the volatile compounds and related sensory quality on virgin olive oil. Eur. J. Lipid Sci. Technol. 2002, 104, 483-489. [CrossRef]

134. Bianco, A.D.; Piperno, A.; Romeo, G.; Uccella, N. NMR experiments of oleuropein biomimetic hydrolysis. J. Agric. Food Chem. 1999, 47, 3665-3668. [CrossRef] [PubMed]

135. Spanier, A.M.; Shahidi, F.; Parliament, T.H.; Mussiman, C.; Ho, C.T.; Tratras Contis, E.; Servili, M.; Selvaggini, R.; Taticchi, A.; Montedoro, G.F. Headspace composition of virgin olive oil evaluated by solid phase microextraction: Relationships with the oil sensory characteristics. In Food Flavors and Chemistry: Advances of the New Millennium; Spanier, A.M., Shahidi, F., Parliment, T.H., Mussinan, C., Ho, C.-T., Tratras Contis, E., Eds.; The Royal Society of Chemistry Publishers: Cambridge, UK, 2001; pp. 236-247. [CrossRef]

136. Servili, M.; Taticchi, A.; Esposto, S.; Urbani, S.; Selvaggini, R.; Montedoro, G.F. Effect of olive stoning on the volatile and phenolic composition of virgin olive oil. J. Agric. Food Chem. 2007, 55, 7028-7035. [CrossRef] [PubMed]

137. Angerosa, F.; Basti, C.; Vito, R.; Lanza, B. Effect of fruit stone removal on the production of virgin olive oil volatile compounds. Food Chem. 1999, 67, 295-299. [CrossRef] 
138. Runcio, A.; Sorgonà, L.; Mincione, A.; Santacaterina, S.; Poiana, M. Volatile compounds of virgin olive oil obtained from Italian cultivars grown in Calabria. Effect of processing methods, cultivar, stone removal, and antracnose attack. Food Chem. 2008, 106, 735-740. [CrossRef]

139. Artajo, L.S.; Romero, M.P.; Suárez, M.; Motilva, M.J. Partition of phenolic compounds during the virgin olive oil industrial extraction process. Eur. Food Res. Technol. 2007, 225, 617-625. [CrossRef]

140. Vierhuis, E.; Servili, M.; Baldioli, M.; Schols, H.A.; Voragen, A.G.J.; Montedoro, G.F. Effect of enzyme treatment during mechanical extraction of olive oil on phenolic compounds and polysaccharides. J. Agric. Food Chem. 2001, 49, 1218-1223. [CrossRef] [PubMed]

141. Servili, M.; Baldioli, M.; Selvaggini, R.; Mariotti, F.; Federici, E.; Montedoro, G.F. Effect of malaxation under $\mathrm{N}_{2}$ flush on phenolic and volatile compounds of virgin olive oil. In Advances in Plant Lipid Researh; Sánchez, J., Cerdá-Olmedo, E., Martínez-Force, E., Eds.; Universidad de Sevilla, Secretariado de Publicaciones: Sevilla, Spain, 1998; pp. 307-310. ISBN 84-472-0481-2.

142. Spencer, C.M.; Cai, Y.; Martin, R.; Gaffney, S.H.; Goulding, P.N.; Magnolato, D.; Lilley, T.H.; Haslam, E. Polyphenol complexation-some thoughts and observations. Phytochemistry 1988, 27, 2397-2409. [CrossRef]

143. Angerosa, F.; Mostallino, R.; Basti, C.; Vito, R. Influence of malaxation temperature and time on the quality of virgin olive oils. Food Chem. 2001, 72, 19-28. [CrossRef]

144. Kalua, C.M.; Bedgood, D.R., Jr.; Bishop, A.G.; Prenzler, P.D. Changes in volatile and phenolic compounds with malaxation time and temperature during virgin olive oil production. J. Agric. Food Chem. 2006, 54, 7641-7651. [CrossRef] [PubMed]

145. Servili, M.; Baldioli, M.; Begliomini, A.L.; Selvaggini, R.; Montedoro, G.F. The phenolic and volatile compounds of virgin olive oil: Relationships with the endogenous oxidoreductases during the mechanical oil extraction process. In Flavour and Fragrance Chemistry; Lanzotti, V., Taglialatela-Scafati, O., Eds.; Kluwer Academic Publishers: Dordrecht, The Netherlands, 2000; pp. 163-173. ISBN 978-0-79-236211-1.

146. Tsimidou, M.; Papadopoulos, G.; Boskou, D. Phenolic compounds and stability of virgin olive oil-Part I. Food Chem. 1992, 45, 141-144. [CrossRef]

147. Servili, M.; Selvaggini, R.; Taticchi, A.; Esposto, S.; Montedoro, G.F. Air exposure time of olive pastes during the extraction process and phenolic and volatile composition of virgin olive oil. J. Am. Oil Chem. Soc. 2003, 80, 685-695. [CrossRef]

148. Servili, M.; Selvaggini, R.; Taticchi, A.; Esposto, S.; Montedoro, G.F. Volatile compounds and phenolic composition of virgin olive oil: Optimization of temperature and time of exposure of olive pastes to air. J. Agric. Food Chem. 2003, 51, 7980-7988. [CrossRef] [PubMed]

149. Morales, M.T.; Angerosa, F.; Aparicio, R. Effect of the extraction conditions of virgin olive oil on the lipoxygenase cascade: Chemical and sensory implications. Grasas y Aceites 1999, 50, 114-121. [CrossRef]

150. Salas, J.J.; Sánchez, J. The decrease of virgin olive oil flavor produced by high malaxation temperature is due to inactivation of hydroperoxide lyase. J. Agric. Food Chem. 1999, 47, 809-812. [CrossRef] [PubMed]

151. Amirante, P.; Catalano, P.; Amirante, R.; Montel, G.; Dugo, G.; LoTurco, V.; Baccioni, L.; Fazio, D.; Mattei, A.; Marotta, F. Estrazione da paste denocciolate. Olivo Olio 2001, 4, 48-55.

152. Di Giovacchino, L.; Solinas, M.; Miccoli, M. Effect of extraction systems on the quality of virgin olive oil. J. Am. Oil Chem. Soc. 1994, 71, 1189-1194. [CrossRef]

153. Montedoro, G.F.; Servili, M. Tradizione e Innovazioni Tecnologiche Nell'estrazione Degli Oli Extravergini di Oliva. In Proceedings of the International Congress "Olive oil quality", Firenze, Italy, 1-3 December 1992; pp. 97-108.

154. Servili, M.; De Stefano, G.; Piacquadio, P.; Di Giovacchino, L.; Sciancalepore, V. Effect of extraction systems on the phenolic composition of virgin olive oils. Eur. J. Lipid Sci. Technol. 1999, 101, 328-332.

155. Welsh, F.W.; Williams, R.E. The use of vegetable oils to recover compound from aqueous solutions. J. Chem. Technol. Biot. 1989, 46, 169-178. [CrossRef]

156. Di Giovacchino, L.; Serraiocco, A. Influenza dei sistemi di lavorazione delle olive sulla composizione dello spazio di testa degli oli. Riv. Ital. Sostanze Gr. 1995, 72, 443-450.

157. Di Giovacchino, L.; Sestili, S.; Di Vincenzo, D. Influence of olive processing on virgin olive oil quality. Eur. J. Lipid Sci. Technol. 2002, 104, 587-601. [CrossRef]

158. Angerosa, F.; Di Giovacchino, L. Natural antioxidants of virgin olive oil obtained by two and tri-phase centrifugal decanters. Grasas y Aceites 1996, 47, 247-254. [CrossRef] 
159. Di Giovacchino, L.; Costantini, N.; Ferrante, M.L.; Serraiocco, A. Influence of malaxation time of olive paste on oil extraction yields and chemical and organoleptic characteristics of virgin olive oil obtained by a centrifugal decanter at water saving. Grasas y Aceites 2002, 53, 179-186. [CrossRef]

160. Di Giovacchino, L.; Costantini, N.; Serraiocco, A.; Surricchio, G.; Basti, C. Natural antioxidants and volatile compounds of virgin olive oils obtained by two and three-phases centrifugal decanters. Eur. J. Lipid Sci. Technol. 2001, 103, 279-285. [CrossRef]

161. Stefanoudaki, E.; Kotsifaki, F.; Koutsaftakis, A. Classification of virgin olive oils of the two major cretan cultivars based on their fatty acid composition. J. Am. Oil Chem. Soc. 1999, 76, 623-626. [CrossRef]

162. Montalegre, C.; Alegre, M.L.; García-Ruiz, C. Traceability markers to the botanical origin in olive oils. J. Agric. Food Chem. 2010, 58, 28-38. [CrossRef] [PubMed]

163. Martins-Lopes, P.; Gomes, S.; Santos, E.; Guedes-Pinto, H. DNA markers for Portuguese olive oil fingerprinting. J. Agric. Food Chem. 2008, 56, 11786-11791. [CrossRef] [PubMed]

164. Muzzalupo, I.; Pellegrino, M.; Perri, E. Detection of DNA in virgin olive oils extracted from destoned fruits. Eur. Food Res. Technol. 2007, 224, 469-475. [CrossRef]

165. Pafundo, S.; Agrimonti, C.; Maestri, E.; Marmiroli, N. Applicability of SCAR markers to food genomics: Olive oil traceability. J. Agric. Food Chem. 2007, 55, 6052-6059. [CrossRef] [PubMed]

166. Pasqualone, A.; Montemurro, C.; Summo, C.; Sabetta, W.; Caponio, F.; Blanco, A. Effectiveness of microsatellite DNA markers in checking the identity of Protected Designation of Origin extra virgin olive oil. J. Agric. Food Chem. 2007, 55, 3857-3862. [CrossRef] [PubMed]

167. Poljuha, D.; Sladonja, B.; Ŝetić, E.; Milotić, A.; Bandelj, D.; Jakŝe, J.; Javornik, B. DNA fingerprinting of olive varieties in Istria (Croatia) by microsatellite markers. Sci. Hortic. 2008, 115, 223-230. [CrossRef]

168. Claros, M.G.; Crespillo, R.; Aguilar, M.L.; Cánovas, F.M. DNA fingerprint and classification of geographically related genotypes of olive-tree (Olea europaea L.). Euphytica 2000, 116, 131-142. [CrossRef]

169. Breton, C.; Claux, D.; Metton, I.; Skorski, G.; Bervill, A. Comparative study of methods for DNA preparation from olive oil samples to identify cultivars SSR alleles in commercial oil samples: Possible forensic applications. J. Agric. Food Chem. 2004, 52, 531-537. [CrossRef] [PubMed]

170. Ayed, R.B.; Grati-Kamoun, N.; Moreau, F.; Rebaï, A. Comparative study of microsatellite profiles of DNA from oil and leaves of two Tunisian olive cultivars. Eur. Food Res. Technol. 2009, 229, 757-762. [CrossRef]

171. Montemurro, C.; Pasqualone, A.; Simeone, R.; Sabetta, W.; Blanco, A. AFLP molecular markers to identify virgin olive oils from a single Italian cultivars. Eur. Food Res. Technol. 2008, 226, 1439-1444. [CrossRef]

172. Consolandi, C.; Palmieri, L.; Severgnini, M.; Maestri, E.; Marmiroli, N.; Agrimonti, C.; Baldoni, L.; Donini, P.; De Bellis, G.; Castiglioni, B. A procedure for olive oil traceability and authenticity: DNA extraction, multiplex PCR and LDR-universal array analysis. Eur. Food Res. Technol. 2008, 227, 1429-1438. [CrossRef]

173. Ceci, L.N.; Carelli, A.A. Characterization of monovarietal Argentinian olive oils from new productive zones. J. Am. Oil Chem. Soc. 2007, 84, 1125-1136. [CrossRef]

174. García-González, D.L.; Luna, G.; Morales, M.T.; Aparicio, R. Stepwise geographical traceability of virgin olive oils by chemical profiles using artificial neural network models. Eur. J. Lipid Sci. Technol. 2009, 111, 1003-1013. [CrossRef]

175. Temime, S.B.; Manai, H.; Methenni, K.; Baccouri, B.; Abaza, L.; Daoud, D.; Casas, J.S.; Bueno, E.O.; Zarrouk, M. Sterolic composition of Chétoui virgin olive oil: Influence of geographical origin. Food Chem. 2008, 110, 368-374. [CrossRef] [PubMed]

176. Angerosa, F.; Mostallino, R.; Basti, C.; Vito, R.; Serraiocco, A. Virgin olive oil differentiation in relation to the extraction methodologies. J. Sci. Food Agric. 2000, 80, 2190-2195. [CrossRef]

177. Morales, M.T.; Aparicio, R. Effect of extraction conditions on sensory quality of virgin olive oil. J. Am. Oil Chem. Soc. 1999, 76, 295-300. [CrossRef]

178. Cunha, S.C.; Casal, S.; Oliveira, M.B.P.P. Triacylglycerol profile by HPLC/ELSD as a discriminant parameter of varietal olive oils from Portugal. Ital. J. Food Sci. 2005, 4, 447-454.

179. D’Imperio, M.; Dugo, G.; Alfa, M.; Mannina, L.; Segre, A.L. Statistical analysis on Sicilian olive oils. Food Chem. 2007, 102, 956-965. [CrossRef]

180. Mannina, L.; Dugo, G.; Salvo, F.; Cicero, L.; Ansanelli, G.; Calcagni, C.; Segre, A. Study of the cultivar-composition relationship in Sicilian olive oils by GC, NMR, and statistical methods. J. Agric. Food Chem. 2003, 51, 120-127. [CrossRef] [PubMed] 
181. Osorio Bueno, E.; Sánchez Casas, J.J.; Martínez Cano, M.; Montaño García, A.M. Estudio del contenido en triglicéridos de aceites monovarietales elaborados a partir de aceitunas producidas en la región extremeña. Grasas y Aceites 2003, 54, 1-6. [CrossRef]

182. Poiana, M.; Mincione, A. Fatty acids evolution and composition of olive oils extracted from different olive cultivars grown in Calabrian area. Grasas y Aceites 2004, 55, 282-290. [CrossRef]

183. Sánchez Casas, J.J.; Osorio Bueno, E.; Montaño García, A.M.; Martínez Cano, M. Estudio del contenido en ácidos grasos de aceites monovarietales elaborados a partir de aceitunas producidas en la región extremeña. Grasas y Aceites 2003, 54, 371-377. [CrossRef]

184. Stefanoudaki, E.; Kotsifaki, F.; Koutsaftakis, A. The potential of HPLC triglyceride profiles for the classification of Cretan olive oils. Food Chem. 1997, 60, 425-432. [CrossRef]

185. Zarrouk, W.; Baccouri, B.; Taamalli, W.; Trigui, A.; Daouda, D.; Zarouka, M. Oil fatty acid composition of eighteen Mediterranean olive varieties cultivated under the arid conditions of Boughrara (southern Tunisia). Grasas y Aceites 2009, 60, 498-506. [CrossRef]

186. Allouche, Y.; Jimenez, A.; Uceda, M.; Aguilera, M.P.; Gaforio, J.J.; Beltran, G. Triterpenic content and chemometric analysis of virgin olive oils from forty olive cultivars. J. Agric. Food Chem. 2009, 57, 3604-3610. [CrossRef] [PubMed]

187. Alves, M.R.; Cunha, S.C.; Amaral, J.S.; Pereira, J.A.; Oliveira, M.B. Classification of PDO olive oils on the basis of their sterol composition by multivariate analysis. Anal. Chim. Acta 2005, 549, 166-178. [CrossRef]

188. Brenes, M.; Garcia, A.; Rios, J.J.; Garcia, P.; Garrido, A. Use of 1-acetoxypinoresinol to authenticate Picual olive oils. Int. J. Food Sci. Technol. 2002, 37, 615-625. [CrossRef]

189. Cerretani, L.; Motilva, M.J.; Romero, M.P.; Bendini, A.; Lercker, G. Pigment profile and chromatic parameters of monovarietal virgin olive oils from different Italian cultivars. Eur. Food Res. Technol. 2008, 226, 1251-1258. [CrossRef]

190. Criado, M.N.; Romero, M.P.; Casanovas, M.; Motilva, M.J. Pigment profile and colour of monovarietal virgin olive oils from Arbequina cultivar obtained during two consecutive crop seasons. Food Chem. 2008, 110, 873-880. [CrossRef] [PubMed]

191. Gandul-Rojas, B.; Mínguez-Mosquera, M.I. Chlorophyll and carotenoid composition in virgin olive oils from various Spanish olive varieties. J. Sci. Food Agric. 1996, 72, 31-39. [CrossRef]

192. Giuffrida, D.; Salvo, F.; Salvo, A.; La Pera, L.; Dugo, G. Pigments composition in monovarietal virgin olive oils from various Sicilian olive varieties. Food Chem. 2007, 101, 833-837. [CrossRef]

193. Koprivnjak, O.; Moret, S.; Populin, T.; Lagazio, C.; Conte, L.S. Variety differentiation of virgin olive oil based on n-alkane profile. Food Chem. 2005, 90, 603-608. [CrossRef]

194. Psomiadou, E.; Tsimidou, M. Pigments in Greek virgin olive oils: Occurrence and levels. J. Sci. Food Agric. 2001, 81, 640-647. [CrossRef]

195. Bianchi, G.; Giansante, L.; Shaw, A.; Kell, D.B. Chemometric criteria for the characterisation of Italian Protected Denomination of Origin (DOP) olive oils from their metabolic profiles. Eur. J. Lipid Sci. Technol. 2001, 103, 141-150. [CrossRef]

196. Galeano Diaz, T.; Durán Meráas, I.; Sánchez Casas, J.; Franco, M.F.A. Characterization of virgin olive oils according to its triglycerides and sterols composition by chemometric methods. Food Control 2005, 16, 339-347. [CrossRef]

197. Giansante, L.; Di Vincenzo, D.; Bianchi, G. Classification of monovarietal Italian olive oils by unsupervised (PCA) and supervised (LDA) chemometrics. J. Sci. Food Agric. 2003, 83, 905-911. [CrossRef]

198. Haddada, F.M.; Manaï, H.; Oueslati, I.; Daoud, D.; Sánchez, J.; Osorio, E.; Zarrouk, M. Fatty acid, triacylglycerol, and phytosterol composition in six Tunisian olive varieties. J. Agric. Food Chem. 2007, 55, 10941-10946. [CrossRef] [PubMed]

199. Haddada, F.M.; Krichene, D.; Manai, H.; Oueslati, I.; Daoud, D.; Zarrouk, M. Analytical evaluation of six monovarietal virgin olive oils from Northern Tunisia. Eur. J. Lipid Sci. Technol. 2008, 110, 905-913. [CrossRef]

200. Stefanoudaki, E.; Kotsifaki, F.; Koutsaftakis, A. Sensory and chemical profiles of three European olive varieties (Olea europea L.); an approach for the characterization and authentication of the extracted oils. J. Sci. Food Agric. 2000, 80, 381-389. [CrossRef]

201. Lorenzo, M.I.; Pavón, P.J.; Laespada, F.M.; Pinto, G.C.; Cordero, M.B.; Henriques, L.R.; Peres, M.F.; Simōes, M.P.; Lopes, P.S. Application of headspace-mass spectrometry for differentiating sources of olive oil. Anal. Bioanal. Chem. 2002, 374, 1205-1211. [CrossRef] [PubMed] 
202. Rivera del Álamo, R.M.; Fregapane, G.; Aranda, F.; Gómez-Alonso, S.; Salvador, M.D. Sterol and alcohol composition of Cornicabra virgin olive oil: The campesterol content exceeds the upper limit of $4 \%$ established by EU regulations. Food Chem. 2004, 84, 533-537. [CrossRef]

203. Tura, D.; Failla, O.; Bassi, D.; Pedò, S.; Serraiocco, A. Cultivar influence on virgin olive (Olea europea L.) oil flavor based on aromatic compounds and sensorial profile. Sci. Hortic. 2008, 118, 139-148. [CrossRef]

204. Lopez-Feria, S.; Cardenas, S.; Garcia-Mesa, J.A. Valcarcel, M. Classification of extra virgin olive oils according to the protected designation of origin, olive variety and geographical origin. Talanta 2008, 75, 937-943. [CrossRef] [PubMed]

205. Angerosa, F.; Basti, C.; Serraiocco, A.; Schiavone, C. Differenziazione Varietale Degli Oli dei Principali Paesi Olivicoli. In Proceedings of the Congress “Germoplasma olivicolo e tipicità dell'olio", Perugia, Italy, 5 December 2003.

206. Angerosa, F.; Basti, C.; Vito, R. Virgin olive oil volatile compounds from lipoxygenase pathway and characterization of some Italian cultivars. J. Agric. Food Chem. 1999, 47, 836-839. [CrossRef] [PubMed]

(C) 2017 by the authors. Licensee MDPI, Basel, Switzerland. This article is an open access article distributed under the terms and conditions of the Creative Commons Attribution (CC BY) license (http:/ / creativecommons.org/licenses/by/4.0/). 